\title{
Platinum in Salt Marsh Sediments: Behavior and Plant Uptake
}

${ }^{1}$ Bioxeoquímica Mariña, Instituto de Investigacións Mariñas IIM-CSIC, Eduardo Cabello 6, 36208 Vigo (Pontevedra), Spain

${ }^{2}$ Instituto Español de Ocenaografía, Centro Oceanográfico de Murcia, Varadero 1, 30740 San Pedro del Pinatar (Murcia), Spain

${ }^{3}$ IPMA-Portuguese Institute of Sea and Atmosphere, Av. Brasilia, 1449-006, Lisbon, Portugal

${ }^{4}$ CIIMAR, Marine and Environmental Research Center, Rua dos Bragas, 289, 4050-123 Porto, Portugal

*corresponding author: $\quad$ calmecija@iim.csic.es

Phone: +34 986231930 (141)

Instituto de Investigacións Mariñas IIM-CSIC

Rúa Edurado Cabello 6, 36208-Vigo (Pontevedra), Spain 


\section{ABSTRACT}

Platinum is one of the least abundant elements in the earth crust with an average concentration of $0.51 \mathrm{ng} \mathrm{g}^{-1}$, but its use in several human activities (mainly automobile catalytic converters) is leading its enrichment in surface sediments. Whereas, previous studies have assessed the Pt behavior in soils from urban areas, natural systems are still poorly studied.

Accordingly, this study is aimed to characterize the behavior of the Pt released to coastal environments in sediments, ascertain the role of vegetation on the biogeochemistry of this element and assess the transference of Pt into the biological compartments. Several sediment cores were sampled in salt marshes (in unvegetated and vegetated areas) of the Tagus Estuary under different traffic pressure. Platinum concentration was analyzed in solid sediment, interstitial water and roots, leaves and stems of Sarcocornia fruticosa, a typical plant in south European salt marshes. In addition, interpretative parameters (e.g. redox potential, dissolved oxygen, $\mathrm{pH}$, total reduced sulfur species, salinity and dissolved Fe and Mn in interstitial waters) were determined to better understand the biogeochemical cycle of Pt in salt marsh sediments.

Although surface enrichment of Pt exists in the sediments at Low Traffic Station (2.8 $\left.\mathrm{ng} \mathrm{g}^{-1}\right)$, the highest enrichment was found at High Traffic Station where concentration was, in some cases, up to $40 \mathrm{ng} \mathrm{g}^{-1}$, linked to traffic emissions. However, dissolved Pt in interstitial waters (from 0.14 to $\left.0.70 \mathrm{ng} \mathrm{L}^{-1}\right)$ did not show this superficial maximum. This dissimilarity points out the unreactivity of traffic-borne Pt and the dissolution/precipitation cycle of natural Pt linked to Mn and $\mathrm{O}_{2}$ cycle, depending on the redox conditions, highly controlled by the vegetation. Platinum concentration in roots $\left(0.9 \pm 0.6 \mathrm{ng} \mathrm{g}^{-1}\right)$ is reflecting the Pt concentration in the interstitial waters in each moment, even though at the two peaks of dissolved Pt (up to $2.5 \mathrm{ng} \mathrm{L}^{-1}$ ) found at deeper layers, reflecting a low bioaccumulation. However, results pointed that a different Pt species (with different bioavailability) may exist in both stations. Besides, Pt mean value in stems and leaves $\left(0.04 \pm 0.05 \mathrm{ng} \mathrm{g}^{-1}\right)$ indicates a low translocation of Pt from the roots to aerial parts.

Therefore, the role of vegetation is fundamental on the geochemical behavior of Pt in sediments, due to the control of the redox conditions by roots in the surrounding sediments (between the $\mathrm{O}_{2}$ release and the organic matter degradation) and leading to Pt species of varying bioavailability.

Keywords: Platinum, Salt Marshes, Tagus Estuary, Sarcocornia fruticosa, geochemical cycle 


\section{INTRODUCTION}

Platinum (Pt) is one of the least abundant elements is the earth crust, due to its extreme affinity to the core (Rauch and Morrison, 2008) where Pt concentration is about 4 orders of magnitude higher than in the upper continental crust $\left(5.5 \mu \mathrm{g} \mathrm{g}^{-1}\right.$ and $0.51 \mathrm{ng} \mathrm{g}^{-1}$ respectively; Lorand et al., 2008; Peucker-Ehrenbrink and Jahn, 2001).

Platinum has been used in several different industrial activities like chemical, biomedical or jewelry, but automobile industry with the production of catalytic converters for engine gas emission reduction, currently represents $40-45 \%$ of the world Pt demand (Brenan, 2008; Johnson Matthey, 2013). Since the 80's, when cars started to use catalytic converters in Europe, $70 \%$ of the European Pt demand was for the manufacturing of catalytic converters (Johnson Matthey, 2013). Previous studies have reported an enrichment in superficial sediments and deposits linked to human activities in urban areas (Fritsche and Meisel, 2004; Rauch et al., 2004a; Schäfer and Puchelt, 1998; Sutherland et al., 2007; Tuit et al., 2000; Whiteley and Murray, 2005) -almost all traffic-borne Pt settles in the first $2 \mathrm{~m}$ away from the road (Fritsche and Meisel, 2004; Helmers and Mergel, 1998; Schäfer and Puchelt, 1998; Zereini et al., 2001), although wind or runoff may vary this dispersion (Schäfer and Puchelt, 1998)- although small fractions of Pt can be transported through the atmosphere to remote environments (Rauch et al., 2004b; Rauch and Morrison, 2008; Sen et al., 2013; Soyol-Erdene et al., 2011). However, some authors revealed that only the $1 \%$ of the anthropogenic Pt is soluble (Ravindra et al., 2004), but the post-depositional reactivity of natural $\mathrm{Pt}$ is unknown, and assessing its potential uptake, accumulation, toxicity to living organisms and transfer through the food web is vital to evaluate it potential risk.

Some studies have analyzed Pt concentration in biological natural samples (Alt et al., 1997, 1988; Beinrohr et al., 1993; Hodge et al., 1986; Pino et al., 2010) or food (Alt et al., 1997; Fragnière et al., 2005; Hoppstock et al., 1989) to ascertain concentrations in different matrices. Others have advanced in the research of the Pt uptake, designing tests where different organisms are grown in model Pt-rich environments (Cosden et al., 2003; Moldovan et al., 2001; Schäfer et al., 1998; Zimmermann et al., 2004) or in natural contaminated ones (Haus et al., 2007; Moldovan et al., 2001; Orecchio and Amorello, 2010; Rauch and Morrison, 1999). Experimental investigations revealed that $\mathrm{Pt}$ is effectively accumulated by terrestrial and aquatic plants and other organisms (Zimmermann and Sures, 2004), reflecting an environmental increase in this element concentration (Cosden et al., 2003; Helmers and Mergel, 1998; Neira et al., 2015; Schäfer et al., 1998). Nevertheless, there is a lack of studies dealing with the longterm accumulation of Pt by plants under natural conditions.

The characteristics of salt marshes and, specially, of their dominant halophytic plant species, which have a strong capability to accumulate contaminants in belowground biomass (e.g. $\mathrm{Pb}$, $\mathrm{Cr}, \mathrm{Zn}, \mathrm{Ni}, \mathrm{Cu}, \mathrm{As}, \mathrm{Cd}, \mathrm{Co}$ ), have been well studied improving the understanding of the biogeochemical cycle of several trace elements (Caçador et al., 2009, 1996; Caetano et al., 2008, 2007; Duarte et al., 2010; Santos-Echeandía et al., 2010; Sundby et al., 2005, 2003; Tanackovic et al., 2008). The ability of these plants to phytostabilize contaminants by uptake is due to their high biomass production (Duarte et al., 2010), and this has entailed their use for 
phytoremediation purposes (Caçador et al., 2009; González-Alcaraz et al., 2011). Therefore salt or transfer to the biological compartments.

The Pt behavior in the sediments of salt marshes is poorly known. Only two previous studies, also in the Tagus estuary salt marshes, reported a high input of traffic-borne Pt in surface sediments (Almécija et al., 2015; Cobelo-García et al., 2011). Thus, sediments, rhizoconcretions, interstitial waters and roots, stems and leaves of Sarcocornia fruticosa (the halophytic specie with the highest biomass; Caçador et al., 2009) were collected from the salt marshes of the Tagus Estuary (SW Europe) at two different sites, with daily extremely different traffic densities. The main objectives of this work are, therefore, to study the Pt behavior and its biological uptake in salt marshes and to investigate the role of the salt marsh plants in the biogeochemical cycle of Pt and its post-depositional mobility.

\section{STUDY AREA}

Tagus Estuary (Figure 1), with a extension of $320 \mathrm{Km}^{2}$ (40\% are salt marshes), is one of the largest estuaries in Europe. The city of Lisbon (Portugal), with 3 million inhabitants, is located in the north bank of the Estuary (Valentim et al., 2013). Salt marsh areas are colonized mainly by Sarcocornia fruticosa (Caryophyllales, Chenopodiaceae), Sarcocornia perennis (Caryophyllales, Chenopodiaceae), Halimione portulacoides (Caryophyllales, Chenopodiaceae) and Sarcocornia maritima (Poales, Poaceae). A typical zonation with homogeneous stands of $S$. maritima as a pioneer species, colonizing bare mud in the lower marsh areas, is found all over the estuary. Across the elevation $(20-50 \mathrm{~cm})$ transect, pure stands of $H$. portulacoides follow $S$. maritima, while S. fruticosa and S. perennis are found in the upper salt marsh. Although the abundance of each changes seasonally or annually due to ecological status, in general the highest biomass corresponds to $S$. fruticosa (Caçador et al., 2009). Marshes are fully inundated twice a day by tidal action (2-4 $\mathrm{m}$ of tidal amplitude) through a highly branched system of channels that cross the elevation transect. These channels have $0.5-1.5 \mathrm{~m}$ depth promoting the inundation of the higher marsh even at low amplitude tides. During the ebb tide water is drained into the channels due to the water table difference.

Two stations, under different traffic pressures, were chosen for sampling: Samouco Salt Marsh or High Traffic Station (Figure 1A) and Rosario Salt Marsh or Low Traffic Station (Figure 1B). High Traffic Station is located under a motorway bridge with a traffic density of 50,000 vehicles per day (Instituto de Intraestructuras Rodoviárias IP de Portugal, 2013). Before the bridge was opened in 1998 the human activities in the area were restricted to local fishing. Conversely, the Low Traffic Station is located in the proximity of a heavy industrialized area that includes several chemical plants. During past decades, these industries had discharged effluents enriched in several contaminants directly into the estuary (Caetano et al., 2007; Mil-Homens et al., 2013), especially $\mathrm{As}, \mathrm{Pb}, \mathrm{Zn}, \mathrm{Cu}$ or $\mathrm{Hg}$ (Vale et al., 2008). Several studies have characterized these inputs into the salt marshes and evaluate how plants behave (Caçador et al., 2009, 1996; Caetano et al., 2008, 2007; Duarte et al., 2010). 


\section{MATERIALS AND METHODS}

\section{Sampling and treatment of samples}

Sediment cores were sampled in the intertidal salt marsh area of the Tagus Estuary in March (spring) and September (summer) 2011. At High Traffic Station (Figure 1A) cores were collected in two different points, one colonized by $S$. fruticosa, and the other without vegetation. At Low Traffic Station cores were taken only where S. fruticosa grows (Figure 1B). Leaves and stems were also sampled at both stations and seasons. Furthermore, some rhizoconcretions that surrounded the roots of $S$. fruticosa, formed by precipitation of Fe oxides in the pores of the sediment grains (Sundby et al., 1998; Vale, 1990), were collected at Low Traffic Station, while in High Traffic Station rhizoconcretions were not found. These structures may account for $4 \%$ of the sediment in the rhizosphere (Vale et al., 2003). Each core was sliced in situ and stored in acid-clean high-density polyethylene bottles, avoiding the air presence inside to minimize oxidation processes in sediments (every $2-\mathrm{cm}$ from 0 to $10 \mathrm{~cm}$, every $3-\mathrm{cm}$ from 10 to $20 \mathrm{~cm}$, every $5-\mathrm{cm}$ from $20 \mathrm{~cm}$ to the bottom of the core). For analyzing Total reduced sulfur species $\left(\mathrm{RSS}_{\mathrm{T}}\right)$ small tubes of centrifuge were also completely filled with sediment (to avoid the oxidation) and frozen.

Sediment samples and rhizoconcretions were oven-dried $\left(<60{ }^{\circ} \mathrm{C}\right)$ until constant weight, homogenized and ground in agate mortar. Live roots (white color) of S. fruticosa were sampled from each sediments layer using a magnifying glass and plastic tweezers. Roots, stems and leaves were rinsed and cleaned with Milli-Q ${ }^{\odot}$ (Millipore) water to eliminate dust or sediment particles, dried $\left(<60^{\circ} \mathrm{C}\right)$ until constant weight and ground. Interstitial waters (first $20 \mathrm{~cm}$ of the core) were extracted from the sediment by centrifugation at $8,000 \mathrm{rpm}$ for 30 minutes at $+4^{\circ} \mathrm{C}$, filtered through $0.45 \mu \mathrm{m}$ polycarbonate membranes, stored in acid-clean low-density polyethylene bottles and acidified using Suprapur $^{\odot}$ (Merck) $\mathrm{HCl}(\mathrm{pH} \sim 1)$. Procedural blanks were also prepared using Milli- $\mathrm{Q}^{\odot}$ water. Figure 2 summarizes the sample treatment procedure. All laboratory material was acid-cleaned prior to use and samples were manipulated inside laminar flow hoods.

\section{Auxiliary parameters}

Interpretative physicochemical parameters (Eh, $\mathrm{pH}$, oxygen saturation and salinity) were measured in situ in duplicate cores using a combined glass electrode with one $\mathrm{Ag} / \mathrm{AgCl}$ reference electrode for $\mathrm{pH}$, while a platinum electrode with a calomel reference electrode was used for Eh measurements. Values of redox potential were corrected for the reference potential of $\mathrm{H}_{2}$. Dissolved oxygen was measured in depth vertical profiles using a Diamond Electro-Tech needle electrode following the method described in Brotas et al. (1990). A refractometer (model Atago S/Milla 0-100\%o) was used to measure salinity in interstitial water.

\section{Analytical methods}

\section{Determination of dissolved $\mathrm{Fe}$ and $\mathrm{Mn}$}

Some dissolved trace elements $(\mathrm{Fe}$ and $\mathrm{Mn}$ ) were determined in interstitial waters by 
electrothermal graphite furnace atomic absorption spectrophotometry (GFAA, Varian SpectrAA previous dilution before the analysis. One blank was run every ten samples and results were blank-corrected.

\section{Determination of $\mathrm{Al}$ in sediments}

Besides, Al was measured by flame atomic absorption spectrophotometry (Varian SpectrAA 220FS) in sediment samples, after an acid digestion -3:1 mixture of $\mathrm{HNO}_{3}$ (Hiperpur@ 69\% Panreac) and HF (Suprapur@ 40\% Merck) - using a microwave oven (MarsXpress, CEM) in Teflon ${ }^{\circledR}$ bombs. The accuracy of $\mathrm{Al}$ analysis was checked using PACS-2 marine sediment reference material (National Researcher council Canada, 2013) and the results obtained were in agreement with the certified values (11.9 \pm 1.2 and $12.6 \pm 0.3 \mathrm{mg} \mathrm{Kg}^{-1}$ respectively).

Total reduced sulfur species in interstitial water

Total reduced sulfur species $\left(\mathrm{RSS}_{\mathrm{T}}\right)$ were determined in interstitial waters by means of cathodic stripping voltammetry (Figure 2) according to Bura-Nakić et al. (2009). Just before the analysis, each sample was melt and centrifuged to extract the interstitial water (avoiding the redox changes). The tubes was open directly into the lab; the aliquot was extracted with a micropipette to be quickly added into the dissolution present in voltammetric cell, previously purged with humidified $\mathrm{N}_{2}$ (99.9999\%; Alphagaz1,AriLiquide). This $\mathrm{RSS}_{\mathrm{T}}$ fraction includes sulfides, polysulfides, organic thiols, polysulfanes and molecular $\mathrm{S}^{0}$.

$\underline{\text { Pt analysis by AdCSV in sediments, roots and interstitial water }}$

Platinum was determined in sediments, rhizoconcretions, roots, leaves, stems and interstitial waters by catalytic adsorptive cathodic stripping voltammetry (catalytic AdCSV) following the method described by van den Berg and Jacinto (1988) and modified by Cobelo-García et al. (2013) (Figure 2).

For sediments, around $200 \mathrm{mg}$ of sample were ashed for $5 \mathrm{~h}$ at $800{ }^{\circ} \mathrm{C}$ in quartz crucibles (Cobelo-García et al., 2011) to remove the organic matter that may severely interfere during the voltammetric determination of Pt. Then, samples were transferred to $30 \mathrm{~mL}$ Teflon ${ }^{\circledR}$ vessels with $5 \mathrm{~mL}$ concentrated $\mathrm{HCl}$ and $3 \mathrm{~mL}$ concentrated $\mathrm{HNO}_{3}$ (Merck Suprapur) and digested on a Teflon-coated hot plate (Pico Trace, $195^{\circ} \mathrm{C}, 4 \mathrm{~h}$ ). After digestion, vessel caps were removed and the acids were allowed to evaporate to near dryness; the residue was then re-dissolved with 1 $\mathrm{mL}$ concentrated $\mathrm{HCl}$ (Merck Suprapur) and $1 \mathrm{~mL}$ concentrated $\mathrm{H}_{2} \mathrm{SO}_{4}$ (Fluka Trace Select) and evaporated again until no fumes were observed (only $\mathrm{H}_{2} \mathrm{SO}_{4}$ remaining) to ensure that there was no $\mathrm{HNO}_{3}$ remnant as it may interfere during the voltammetric determination. Samples were cooled, diluted with $0.1 \mathrm{M} \mathrm{HCl}$, syringe-filtered $(0.45 \mu \mathrm{m})$ and made up to $25 \mathrm{~mL}$ in volumetric flasks. This method was also used for Pt determination in vegetal tissues, except for the ashing conditions; here, a temperature of $650{ }^{\circ} \mathrm{C}$ for $16 \mathrm{~h}$ was chosen $\left(800{ }^{\circ} \mathrm{C}\right.$ caused some problems with samples). Blanks for Pt in sediments and vegetal tissues were calculated $(0.024 \pm 0.004$ and $0.057 \pm 0.018 \mathrm{ng} \mathrm{g}^{-1}$, respectively; detection limits Supplementary Data Table S-1). All samples in the study are blank corrected. The road dust certified reference material BCR-723 (Institute of Reference Materials and Measurements, 2013) was analyzed to check the accuracy 
of the analytical procedure, yielding a close agreement with the certified concentration (recovery $100 \%$, certified value $81.3 \pm 2.5 \mathrm{ng} \mathrm{g}^{-1}$, this study value $81.5 \pm 6.3 \mathrm{ng} \mathrm{g}^{-1}$, Table S-1).

For interstitial waters, samples were diluted (1:11) and UV-digested $(4 \mathrm{~h})$ in the presence of 22 $\mathrm{mM} \mathrm{H}_{2} \mathrm{O}_{2}$ (TraceSelect ${ }^{\circledR}$ Ultra, Fluka) to remove organic matter (Almécija et al., 2015; CobeloGarcía et al., 2013). Blanks $\left(0.003 \pm 0.003 \mathrm{ng} \mathrm{L}^{-1}\right)$ and detection limits are also calculated (values in Table S-1). All the results given are blank-corrected.

\section{Biomass and loss on ignition (LOI)}

Other parameters determined to help in the interpretation of the results were the biomass and loss on ignition (LOI). Biomass weight (\%) was calculated following the equation:

$$
\text { Biomass }(\%)=\frac{\text { Weight }_{\text {roots slice }}}{\text { Weight }_{\text {slice }}} \times 100 \quad \text { [Eq 1] }
$$

where Weight $t_{\text {roots slice }}$ is the weight of the roots in each slice and Weight $t_{\text {slice }}$ is the weight of the entire slice.

The loss on ignition $\left(\mathrm{LOI}_{550}{ }^{\circ} \mathrm{C}, \%\right)$ was calculated following the method proposed by (Heiri et al., 2001) to approximate the organic content in sediments.

$$
L O I_{5500^{\circ} \mathrm{C}}=\frac{D w_{105^{\circ} \mathrm{C}-D w_{550}{ }^{\circ} \mathrm{C}}}{D w_{105}{ }^{\circ} \mathrm{C}} \times 100
$$

where $D w_{105}{ }^{\circ} \mathrm{C}$ is the weight of the sediment after $16 \mathrm{~h}$ ashing at $105{ }^{\circ} \mathrm{C}$, for achieving a constant dry weight of the sample, and $D w_{550}{ }^{\circ} \mathrm{C}$ is the weight of the same sample ashed again at $550{ }^{\circ} \mathrm{C}$ during $16 \mathrm{~h}$, to combust organic matter.

\section{RESULTS}

Auxiliary parameters and analysis

\section{$\underline{\text { Auxiliary parameters }}$}

Figure 3 shows the dissolved oxygen (\%) and redox potential (Eh, $\mathrm{mV}$ vs. $\mathrm{H}^{+}$) at both stations for unvegetated and vegetated cores, in spring (upper panel) and summer (lower panel). At High Traffic Station, dissolved oxygen was under the detection limit for unvegetated cores in both seasons, except for upper 2-cm (2\%) in spring where the saturation was up to $9.5 \%$ (Table 1). However, for vegetated cores, oxygen profiles showed clear distinctive conditions: up to $20 \%$ of oxygen (95\% saturation) in spring but below the detection limit in summer throughout the core (Table 1). At Low Traffic Station oxygen was present in spring in the first $20 \mathrm{~cm}(2.4-86 \%$ of oxygen saturation, Table 1), whereas in summer oxygen appeared from 5 to $20 \mathrm{~cm}(0.95-30$ $\%$ of oxygen saturation, Table 1 ).

The redox potential values showed a general trend to increase from top to bottom at High Traffic Station for both seasons and vegetation conditions, between -66 and $210 \mathrm{mV}$ for unvegetated and -100 to $180 \mathrm{mV}$ for vegetated (summer, Figure 3 and Table 1). Conversely, at Low Traffic Station, the highest values were found in the more oxygenated part of the cores (spring: $270 \pm 60 \mathrm{mV}, n=8$; summer: $270 \pm 36, n=21$ ) and when oxygen was depleted Eh 
decreased (spring: $-53 \pm 28, n=5$; summer: $86 \pm 33, n=9$ ). Eh behavior was quite similar in both sampling dates.

At High Traffic Station pH decreased with depth (from 7.44 to 6.60 and 7.66 to 6.71 in spring and summer respectively for unvegetated samples; from 7.07 to 6.63 and from 6.95 to 6.24 in spring and summer, respectively for vegetated samples; Table 1), whereas at Low Traffic Station $\mathrm{pH}$ profile showed a decreasing trend in summer core, from $6.41(\mathrm{z}=0.5 \mathrm{~cm})$ to $5.9(\mathrm{z}=$ $16.5 \mathrm{~cm})$, but this variation was not clear in the spring $(6.35 \pm 0.06, n=30)$. The salinity varied from the top of the core to the bottom showing the opposite behavior to $\mathrm{pH}$ in both seasons and stations (ranging between 20 to 40 and from 17 to 40 for unvegetated and vegetated cores at High Traffic Station and from 22 to 51 at Low Traffic Station, Table 1). Besides, summer always exhibit higher salinity than spring.

Biomass and loss on ignition (LOI)

At High Traffic Station, the loss on ignition $\left(\mathrm{LOI}_{550}{ }^{\circ} \mathrm{C}\right)$ had homogeneous values in both cores for spring (unvegetated: $4.2 \pm 1.2 \%, n=13$; vegetated: $4.1 \pm 1.3 \%, n=18$, Figure 4), whereas in summer, the profiles showed an enrichment in the upper $4 \mathrm{~cm}$ (up to $20 \%$ in surface for both vegetation conditions). Besides, $\mathrm{LOI}_{550}{ }^{\circ} \mathrm{C}$ and root biomass (\%) displayed similar profiles in summer, while in summer differences appeared in the samples deeper than 10-cm where LOI was usually 2 times the biomass. At Low Traffic Station, calculations of biomass and $\mathrm{LOI}_{550}{ }^{\circ} \mathrm{C}$ also presented values similar in all the profile (spring; LOI $=7 \pm 3 \%, n=18$, and biomass $=7 \pm 2$ $\%, n=9$; summer: $\mathrm{LOI}=7 \pm 2 \%, n=17$, and biomass $=5 \pm 1 \%, n=8$ ).

Dissolved Fe, Mn and Total reduced sulfur species $\left(\mathrm{RSS}_{\mathrm{T}}\right)$ in interstitial waters

Figure 5 showed $\mathrm{Fe}, \mathrm{Mn}$ and total reduced sulfur species $\left(\mathrm{RSS}_{\mathrm{T}}\right)$ profiles in interstitial waters in the first $20 \mathrm{~cm}$ for both sampling station and seasons. Unvegetated cores from High Traffic Station, presented peaks in both samplings that became smoother in spring. Dissolved Fe ranged from 0.05 to $0.19 \mathrm{mg} \mathrm{L}^{-1}$ (peak at $<2 \mathrm{~cm}$ ) in spring and 0.04 to $11.0 \mathrm{mg} \mathrm{L}^{-1}$ (peak at 5-cm depth) in summer. Dissolved Mn varied from 0.46 to $1.2 \mathrm{mg} \mathrm{L}^{-1}$ in spring and from 0.50 to $2.8 \mathrm{mg} \mathrm{L}^{-1}$ in summer (peak at 7-cm depth and around 3 times higher in summer). The highest difference appeared in $\mathrm{RSS}_{\mathrm{T}}$ values, where spring and summer data ranged between 1.7-8.8 $\mu \mathrm{g} \mathrm{L}^{-1}$ and 5.414000 to $\mu \mathrm{g} \mathrm{L}^{-1}$ respectively, both showing surface peaks (Tables S-2 for spring and Table S-3 for summer, Supplementary Data). In the same sampling station, vegetated cores presented subsurface peaks in both cores for the redox sensitive elements, Fe and Mn (Figure 4, Table S-4 for spring and Table S-5 for summer, Supplementary Data). Iron concentrations in interstitial waters were similar in spring and summer, ranging from 1.9 and $12.0 \mathrm{mg} \mathrm{L}^{-1}$ (peak centered at $7 \mathrm{~cm}$ depth) and 0.34 and $78.0 \mathrm{mg} \mathrm{L}^{-1}$ (maximum at $10 \mathrm{~cm}$ ), accordingly. Minima values were observed in the uppermost layers of both cores. Similarly, Mn profiles (1.3-2.7 $\mathrm{mg} \mathrm{L}^{-1}$ in spring; $0.39-3.5 \mathrm{mg} \mathrm{L}^{-1}$ in summer) showed the minimum at surface and the maximum around $15 \mathrm{~cm}$. Total dissolved reduced sulfur species $\left(\mathrm{RSS}_{\mathrm{T}}\right.$ ) concentrations followed a similar pattern in both sampling dates: a surface maximum followed by a minimum and a deeper sub-surface maximum (spring: 1.0-180 $\mu \mathrm{g} \mathrm{L}{ }^{-1}$ and max. at $5 \mathrm{~cm}$; summer: $14-300 \mu \mathrm{g} \mathrm{L}^{-1}$ and max. at $7 \mathrm{~cm}$ ).

At Low Traffic Station, vertical profiles of dissolved Fe, Mn and $\mathrm{RSS}_{\mathrm{T}}$ in interstitial water 
exhibited a surface maximum concentration in the summer $\left(0.58\right.$ and $5.0 \mathrm{mg} \mathrm{L}^{-1}$ for Fe and $\mathrm{Mn}$, and $76 \mu \mathrm{g} \mathrm{L}^{-1}$ for $\mathrm{RSS}_{\mathrm{T}}$ ), while in spring only Mn presented a surface peak (6.3 $\left.\mathrm{mg} \mathrm{L}^{-1}\right)$. In this sampling date $\mathrm{RSS}_{\mathrm{T}}$ reached a maximum at $2-4 \mathrm{~cm}\left(81 \mu \mathrm{g} \mathrm{L}^{-1}\right)$ whereas for Fe a maximum was observed at $14.5 \mathrm{~cm}\left(6.7 \mathrm{mg} \mathrm{L}^{-1}\right)$.

\section{Pt concentration in different fractions}

Platinum in interstitial water

Figure 6 exhibits Pt concentrations in interstitial waters in the first $20 \mathrm{~cm}$ for both sampling station and seasons. An increasing trend with depth in both cores was found for unvegetated samples (High Traffic Station), being progressive in spring, between 0.26 and $0.41 \mathrm{ng} \mathrm{L}^{-1}$, and more evident in the first 6-cm in summer, ranging between 0.43 and $0.66 \mathrm{ng} \mathrm{L}^{-1}$ (Figure 3, and Tables S-2 and Table S-3 in Supplementary Data). However, this trend was not so evident for vegetated samples (High Traffic Station) where interstitial water presented similar profiles of dissolved Pt with depth, $0.52 \pm 0.08 \mathrm{ng} \mathrm{L}^{-1}$ in spring and $0.40 \pm 0.06 \mathrm{ng} \mathrm{L}^{-1}$ in summer, except for a peak of $1.9 \mathrm{ng} \mathrm{L}^{-1}$ in the deepest sample in summer $(18 \mathrm{~cm})$. At Low Traffic Station, dissolved $\mathrm{Pt}$ in interstitial water remained relatively constant in both samplings $\left(0.21 \pm 0.07 \mathrm{ng} \mathrm{L}^{-1}, n=7\right.$ in spring and $0.48 \pm 0.09 \mathrm{ng} \mathrm{L}^{-1}, n=8$ in summer), except for a peak 12-fold the average concentration in spring $\left(2.5 \mathrm{ng} \mathrm{L}^{-1}, 14.5 \mathrm{~cm}\right)$.

\section{$\underline{\text { Platinum in Sediments }}$}

In sediments, Pt concentrations varied from 0.47 to $0.99 \mathrm{ng} \mathrm{g}^{-1}$ and from 0.45 to $40 \mathrm{ng} \mathrm{g}^{-1}$ in spring and summer unvegetated cores, respectively (High Traffic Station, Figure 7, and Tables S-2 and Table S-3 in Supplementary Data). Only the upper 4-cm showed evident differences between both cores: homogeneous in spring and with a clear surface peak in summer (40 $\mathrm{ng} \mathrm{g}^{-1}$ at $<2 \mathrm{~cm}, 2.5 \mathrm{ng} \mathrm{g}^{-1}$ at 2-4 cm). These values were normalized to $\mathrm{Al}$ content which is a proxy for sediment nature and minimizes the differences associated with changes in particle nature and grain size (Sageman and Lyons, 2003; Windom et al., 1989). Vegetated cores in the same station showed higher concentrations at 2-4 $\mathrm{cm}\left(1.1 \mathrm{ng} \mathrm{g}^{-1}\right)$ in spring and at $0-2 \mathrm{~cm}$ reaching $5.5 \mathrm{ng} \mathrm{g}^{-1}$ in summer, 10-fold the mean value. Levels in deeper layers averaged very similar in both samplings, $0.56 \pm 0.21 \mathrm{ng} \mathrm{g}^{-1}(n=18)$ in spring and $0.54 \pm 0.14 \mathrm{ng} \mathrm{g}^{-1}(n=12)$ in summer. At Low Traffic Station, $\mathrm{Pt}$ in both profiles increased towards the top of the cores. Concentrations ranged from 2.8 to $0.022 \mathrm{ng} \mathrm{g}^{-1}$ in spring and from 1.1 to $0.11 \mathrm{ng} \mathrm{g}^{-1}$ in summer. At this station, the distribution of Pt was also measured in rhizoconcretions at millimeter scale. From inner (0-1 $\mathrm{mm}$ ) to outer layer (4-5 mm), levels were: $1.1 \mathrm{ng} \mathrm{g}^{-1}, 0.7$ and 0.9 respectively (Table 2).

$\underline{\text { Platinum in roots, stems and leaves }}$

Pt in roots of S. fruticosa (Figure 7) showed concentrations from 0.21 to $1.5 \mathrm{ng} \mathrm{g}^{-1}$ in spring and 0.027 to $0.39 \mathrm{ng} \mathrm{g}^{-1}$ in summer at High Traffic Station, and was in the range of the values for the surrounding sediments. Nevertheless, and in opposition to the sediment trend, roots revealed a clear increase with depth (Figure 7, Tables S-4 and Table S-5, Supplementary Data). At Low Traffic Station, Pt concentrations ranging between 0.18 and $1.6 \mathrm{ng} \mathrm{g}^{-1}$ in spring, whose trend is decreasing with depth except for a peak at $15 \mathrm{~cm}$, and between 0.18 and $1.1 \mathrm{ng} \mathrm{g}^{-1}$ in summer (Table 2 and Figure 5; Table S-6 and Table S-7 Supplementary Data). 
On the other hand, analysis of Pt in aboveground plant parts (stems and leaves) of $S$. fruticosa roots, in fact under the detection limit for some samples. At High Traffic Station, for spring samples Pt in leaves $\left(0.039 \mathrm{ng} \mathrm{g}^{-1}\right)$ was higher than in stem $\left(0.015 \mathrm{ng} \mathrm{g}^{-1}\right)$, while in summer Pt was not detected in leaves and showed the same content in stems $\left(0.012 \mathrm{ng} \mathrm{g}^{-1}\right)$. However, Pt concentrations al Low Traffic Station were $0.086 \mathrm{ng} \mathrm{g}^{-1}$ for stems and $0.13 \mathrm{ng} \mathrm{g}^{-1}$ for leaves in spring, but below the detection limit in both samples for summer (Table 2).

\section{DISCUSSION}

\section{Platinum chemistry between sediments and interstitial water}

Concentrations of $\mathrm{Pt}$ in sediments exhibit, in general, a surface enrichment, especially evident in the Al-normalized data (Figure 7), except for some cores where surface sample could be damaged but the trend exists. These results are in line with the findings of Cobelo-García et al. (2011) and Almécija et al. (2015) in salt marsh sediments of Tagus estuary, the only existing data of Pt in any salt marsh. The highest Pt concentration was found in the surface layer at High Traffic Station (40.1 $\mathrm{ng} \mathrm{g}^{-1}$ ), which is almost 80 times the average continental crust abundance $\left(0.51 \mathrm{ng} \mathrm{g}^{-1}\right.$; Peucker-Ehrenbrink and Jahn, 2001) and 65 times the averaged local background $\left(0.62 \pm 0.14 \mathrm{ng} \mathrm{g}^{-1}\right.$, Table S-8). Besides, this surface high concentration exceeds the Pt concentration found in similar environments (Table S-8), overtaking 20 times Pt-moderatecontaminated estuarine sediments (Cobelo-García et al., 2013) and two orders of magnitude a pristine coastal lagoon sediments (Prego et al., 2011). These high concentrations agree with surface enrichments linked with traffic-borne contamination that have been reported in harbors (Tuit et al., 2000), urban lakes (Rauch et al., 2004a), sediments nearby road soils (Schäfer and Puchelt, 1998) and collectors of urban runoff and gullypots (Fritsche and Meisel, 2004; Schäfer and Puchelt, 1998; Sutherland et al., 2007; Whiteley and Murray, 2005) pointing to a contamination by traffic especially at High Traffic Station (Data in Supplementary Data, Table S-8). Therefore, in the first 2 or 4 centimeters Pt is consider mostly human-derived (until 99 and $78 \%$ of surface Pt has anthropogenic origin at High and Low Traffic Station respectively; Almécija et al., 2015); deeper Pt has a natural origin, similar to average continental crust values (see values above).

In interstitial waters $\mathrm{Pt}$ varied within a narrow range $\left(0.26-0.66 \mathrm{ng} \mathrm{L}^{-1}\right.$ for unvegetated cores; 0.14-0.70 ng $\mathrm{L}^{-1}$ for vegetated cores), exhibiting a slight increase of dissolved Pt with depth (Figure 6). Exceptionally, two maxima of dissolved Pt were found in the deepest part of the vegetates cores $\left(1.9 \mathrm{ng} \mathrm{L}^{-1}\right.$ at $18 \mathrm{~cm}$ for summer at High Traffic Station and $2.5 \mathrm{ng} \mathrm{L}^{-1}$ at 14.5 $\mathrm{cm}$ for spring at Low Traffic station). For unvegetated and vegetated cores, dissolved Pt was up to one order of magnitude higher than values found in estuarine waters from several rivers (Cobelo-García et al., 2013; Obata et al., 2006; Turetta et al., 2003). This difference was even higher when comparing to oceanic waters (0.02-0.08 ng L-1 Colodner, 1991). Consequently, the ratios of $\mathrm{Pt}$ concentration between interstitial and oceanic waters are 2-125. This low ratio was also found for other highly reactive elements (Table S-9), like Fe and Mn or even for $\mathrm{Cd}, \mathrm{Zn}, \mathrm{Cu}$ 
that are removed by plant roots (Caetano et al., 1997; Santos-Echeandía et al., 2010). In the salt Pt-complexes (Colombo et al., 2008; Reith et al., 2014), being $\mathrm{PtCl}_{5}(\mathrm{OH})^{2-}$ the dominant species accordingly to (Cobelo-García et al., 2013). Previous studies also concluded that under oxicsuboxic conditions natural dissolved Pt predominates in the IV oxidation state, which is the thermodynamic most stable form at $\mathrm{pH}$ closer to the 8 and oxygen-rich environment (CobeloGarcía et al., 2013). This finding was also in line with the work of Cosden et al. (2003) that measure fast oxidation rates of $\mathrm{Pt}(\mathrm{II})$ to $\mathrm{Pt}(\mathrm{IV})$ in seawater.

Noticeably, the surface Pt-enrichment in sediments is not reflected in the interstitial waters. Here, two explanations may be invoked: (i) the settled Pt are in particulate form, being inert or having low dissolution or solubilization reaction kinetics, and/or (ii) the precipitation of $\mathrm{Fe}$ and Mn oxyhydroxides in topmost sediments scavenges or adsorbs the dissolved Pt or makes Pt coprecipitate with them. Previous studies reported that less than $1 \%$ of $\mathrm{Pt}$ is able to be in a soluble form (Ravindra et al., 2004). Therefore, catalytic-converters-derived Pt remains almost inert in the sediment. However, for understand natural Pt behavior, partition coefficients $K_{d}\left(K_{d}=\right.$ [Pt]sediment/[Pt]interstitial water, $\mathrm{L} \mathrm{Kg}^{-1}$; where [Pt]sediment is expressed in $\mathrm{ng} \mathrm{Kg}^{-1}$ and [Pt]interstitial water in $\mathrm{n} \mathrm{L} \mathrm{L}^{-1}$ ), were calculated for the samples deeper than 4-cm depth and plotted against different parameters analyzed in interstitial water. Dissolved Mn shows an inverse statistically significant relationship with $K_{d}(\mathrm{p}<0.05, \mathrm{r}=0.3826)$, suggesting a close relationship with dissolved Pt, as it is shown in the Figure 8: the higher is the dissolved $\mathrm{Mn}$, the lower is the $K_{d}$-higher the dissolved $\mathrm{Pt}-$. Previous studies pointed to the possible coprecipitation or sorption of $\mathrm{Pt}$ during formation of $\mathrm{Fe}-\mathrm{Mn}$ oxides and oxyhydroxides in ferromanganese nodules and crusts at the seafloor (Asavin et al., 2009; Halbach et al., 1989; Hein and Koschinsky, 2014; Koschinsky and Hein, 2003) and in other sedimentary environments (Cobelo-García et al., 2011; Colodner et al., 1992; Wei and Morrison, 1994). In fact, the Pt-enrichment of ferromanganese crust and nodules has been considered as potential significant source of Pt to the environment when they dissolve (Hein et al., 2000). However, despites some previous studies exist (Halbach et al. 1989) the possible formation mechanisms are still not well constrained (co-precipitation, adsorption, etc.).

Thus, we propose that this mechanism may occur in two different situations. In unvegetated sediments, dissolved oxygen diffuses into the sediment and oxidizes the Mn reduced forms, generating a surface peak of Mn, but also of Pt, in sediments (data in Supplementary Data Table S-2 and Table S-3). However, the presence of traffic-borne Pt in the sediments (99\% of Pt comes from an anthropogenic source, Almécija et al., 2015) could mask the redox-related Pt precipitation. In vegetated sediments, besides the oxygen penetration from surface (water or air), the release of oxygen also occurs through the roots that oxidize the reduced species in the rhizosphere (Sundby et al., 2003). Previous authors (Caetano and Vale, 2002; Sundby et al., 1998; Vale et al., 2003) revealed that when an oxygen-supplying root grows into anoxic sediment in the beginning of a new growth season (spring, Figure 9A), oxidation takes place first in the thin sediment layer immediately adjacent to the root wall. In this moment the rhizosphere constitutes an environment in which amorphous sulphides (mainly FeS, grown during the anoxic seasons; Caetano and Vale, 2002) are oxidized releasing reduced forms of Fe, 
Mn and intermediate oxidized phases of sulfurs to interstitial waters (Madureira, 1997), as well reduced $\mathrm{Fe}$ and $\mathrm{Mn}$ generating oxihydroxides favoring the formation of rhizoconcrections (Caetano and Vale, 2002; Sundby et al., 1998). At this stage dissolved Pt may be retained by coprecipitation, sorption or scavenge in the Fe-Mn oxyhydroxides (Kubrakova et al., 2011), agreeing with the Mn-Pt relationship found (see above). Accordingly, during their grown rhizoconcretions show a similar Fe-Pt-enriched compared to $\mathrm{Fe}$ and $\mathrm{Pt}$ concentrations in the surrounding sediments (Table 2). When growth station ends (Figure 9C), roots stop to release $\mathrm{O}_{2}$ and the remaining $\mathrm{O}_{2}$ is being used in the organic matter degradation (Sundby et al., 2005). Afterwards the complete depletion of $\mathrm{O}_{2}$ this degradation starts to consume those oxides, like Mn (IV) and Fe (III), as electron acceptors (Figure 9D), releasing Mn (II) and Fe(II) to the interstitial water, as well as, other elements co-precipitated in Fe-Mn oxyhydroxides. Two peaks of dissolved Pt coincided with dissolved $\mathrm{Fe}$ and Mn peaks, suggesting this mobilization of Pt to interstitial water may be related with redox reactions for the organic matter degradation. Finally, conditions will be suitable to form, again, amorphous FeS that might scavenge dissolved Pt in their precipitation passing $\mathrm{Pt}$ to the solid fraction (Figure 9E). The presence of anthropogenic Pt, that remains inert (as we have mentioned before) could hide this Pt increase in the sediments. Thus, a record of solid natural Pt in vegetated sediment may be restricted to a growing season (with Fe-Mn oxyhydroxides) and the anoxic events (with FeS), being an annual turnover rate expected for this element in vegetated sediments (Figure 9), while the anthropogenic Pt settles inert to these processes.

\section{Effect of salt marsh plants activity on Pt behavior}

Salt marsh plants have the ability to concentrate anthropogenically-born elements in their belowground biomass (Caetano et al., 2008), exceeding several orders of magnitude levels in sediments (Figure 10), becoming the roots an essential vector for the biogeochemistry of the surrounding sediments (Caetano et al., 2008; Sundby et al., 2005, 2003). Thus to clarify whether the increase of $\mathrm{Pt}$ in belowground plant parts resulted from the availability in sediments or controlled by plant activity, enrichment factors ( $\mathrm{EF}=[$ Pt]roots/[Pt]sediment, (Caetano et al., 2008) were calculated for each sediment layer. Enrichment factor in roots of S. fruticosa from High Traffic Station $(1.0 \pm 0.7 ; n=26)$ were comparable to values obtained in the Low Traffic Station $(0.7 \pm 0.5 ; n=17)$. Thus, no measurable record of Pt mobilization was found in the rhizosphere as a result of the root activity of S. fruticosa. This weak Pt removal is in line with other studies that concluded that Pt behaves as immobile element, avoiding to be integrated into the food chain, even though in those experiments made with high concentrations of $\mathrm{Pt}$ in the sediments (Hoppstock et al., 1989; Lustig et al., 1997; Orecchio and Amorello, 2010; Schäfer et al., 1998).

Figure 11 indicates Pt concentration in $S$. fruticosa roots is reflecting the Pt concentration in surrounding interstitial waters, being statistically significant $(\mathrm{p}<0.05)$ in both sampling Stations. Consequently, the Pt-enrichment is a reversible state, being accumulated or released in different moments. Observing more in detail, for the same Pt concentration in interstitial water, Pt concentration is higher in S. fruticosa roots from Low Traffic Station than roots from High 
Traffic Station, what suggests a different availability of Pt soluble forms in the rhizosphere. On the different Pt speciation, when salinity increases, agreeing with the results found for Pt in roots that point to differences in Pt between both marshes. In fact, higher salinity was found in Low Traffic Station (until 51) resulting a more bioavailable Pt forms in interstitial waters from this marsh (Figure 11). These findings suggest that different Pt-species exist in each station, reflecting oxygen saturation, salinity, $\mathrm{pH}$ and redox status (derived from plant activity). Since roots uptake the surrounding interstitial water, the chemical perturbations that this water undergoes will be reflected in the uptake by roots. In this way, the singularity found at Low Traffic Station may be explained, where the Pt peak in spring roots at $14 \mathrm{~cm}$ (Figure 6 and Figure 7, Low Traffic Station, spring) reached $1.6 \mathrm{ng} \mathrm{g}^{-1}$, matching the Pt peak in interstitial water $\left(2.5 \mathrm{ng} \mathrm{L}^{-1}\right)$.

\section{Pt translocation in Sarcocornia Fruticosa tissues}

Pt concentration in roots was up to 30 times higher than in stems and leaves (no significant differences were found between leaves and stems) indicating that either plants do not transport Pt to aboveground tissues or the translocation may exists but Pt retention in chlorophyll tissues is not efficient (Table S-10). Low Pt translocation to the aerial parts of plants has been documented in other species (Ravindra et al., 2004). In fact, previous studies in below and aboveground parts of $S$. fruticosa found also low translocation for other elements (Table S-10; Caçador et al., 2009; Caetano et al., 2008) exhibiting higher concentrations in roots that in the other tissues (2-4 orders of magnitude), especially for $\mathrm{Fe}, \mathrm{Ni}, \mathrm{Cu}, \mathrm{Zn}, \mathrm{As}$ or $\mathrm{Cd}$. Therefore, the active biogeochemical cycle of these elements, as well as Pt, occurs in the belowground parts. Nonetheless, although concentrations in roots are always higher than in aerial parts of $S$. fruticosa, the concentration of $\mathrm{Pt}$ in the aboveground biomass is not negligible. Detritus derived from the aerial tissues, strongly variable with the seasons, could be an important source of this contaminant before being buried, especially because these organic rests can be easily transported by wind and runoff to adjacent marsh areas (Caçador et al., 2009).

\section{CONCLUSIONS}

While the traffic-borne Pt remains mostly inert in the first centimeters of sediments, natural Pt is closely linked to Mn geochemical cycle. In unvegetated sediments the penetration of $\mathrm{O}_{2}$ by diffusion rules the presented phases, while in vegetated sediments the role of vegetation is fundamental in the behavior of Pt. Roots of halophytic plants control the geochemistry in the surrounding sediments (redox conditions, presence of $\mathrm{O}_{2}$, organic matter degradation) that determine the chemical species in solid and dissolved phases. Therefore Pt in vegetated sediments is involved in an annual turnover, controlled by plants activity and linked to Mn cycle. Similar relationship bewteen Pt-Mn was found in Fe-Mn crusts and nodules, that pinpoints to a Pt co-precipitation/adsorbing/scavenging processes in the Mn-oxides formation.

The halophytic plant Sarcocornia fruticosa lack the strong capability they show to accumulate other anthropogenic contaminants by their belowground biomass. The Pt concentration in roots 
reflects the Pt concentration in interstitial waters at every moment. However the surrounding conditions control the formation of different chemical species, with different bioavailability. Low translocation of Pt to the aerial tissues, indicate the absence of a real Pt-accumulation and the Pt incorporation to the food chain.

\section{ACKNOWLEDGEMETNS}

The CSIC, under the program JAE (Junta para la Ampliación de Estudios) co-funded by the Fondo Social Europeo (FSE), is greatly acknowledge for the predoctoral and post-doctoral fellowships to C. Almécija and J. Santos-Echeandía, respectively. We also thank the Universidade de Vigo and Facultade de Ciencias do Mar for the $\mathrm{PhD}$ program in Oceanography and for funding for the Almécija's short researcher stay in IPMA. Thanks to Susana Calvo (IIMCSIC) and Joana Raimundo (IPMA) for technical work.

\section{REFERENCES}

Almécija, C., Sharma, M., Cobelo-García, A., Santos-Echeandía, J., Caetano, M., 2015. Osmium and Platinum Decoupling in the Environment: Evidences in Intertidal Sediments (Tagus Estuary, SW Europe). Environ. Sci. Technol. 49, 6545-6553.

Alt, F., Eschnauer, H.R., Mergler, B., Messerschmidt, J., Tölg, G., 1997. A contribution to the ecology and enology of platinum. Fresenius J. Anal. Chem. 357, 1013-1019.

Alt, F., Jerono, U., Messerschmidt, J., Tölg, G., 1988. The determination of platinum in biotic and environmental materials, I. $\mu \mathrm{g} / \mathrm{kg}$-to g/kg-range. Microchim. Acta 96, 299-304.

Asavin, A.M., Anikeeva, L.I., Kazakova, V.A., Andreev, S.I., Sapozhnikov, D.A., Roshchina, I.A., Kogarko, L.N., 2009. Trace element and PGE distribution in layered ferromanganese crusts. Geochem. Int. 46, 1179-1205.

Beinrohr, E., Lee, M.L., Tschöpel, P., Tölg, G., 1993. Determination of platinum in biotic and environmental samples by graphite furnace atomic absorption spectrometry after its electrodeposition into a graphite tube packed with reticulated vitreous carbon. Fresenius J. Anal. Chem. 346, 689-692.

Brenan, J.M., 2008. The platinum-group elements:"Admirably adapted" for science and industry. Elements 4, 227-232.

Brotas, V., Amorim-Ferreira, A., Vale, C., Catarino, F., 1990. Oxygen profiles in intertidal sediments of Ria Formosa (S. Portugal). Hydrobiologia 207, 123-130.

Bura-Nakić, E., Viollier, E., Jézéquel, D., Thiam, A., Ciglenečki, I., 2009. Reduced sulfur and iron species in anoxic water column of meromictic crater Lake Pavin (Massif Central, France). Chem. Geol. 266, 311-317.

Caçador, I., Caetano, M., Duarte, B., Vale, C., 2009. Stock and losses of trace metals from salt marsh plants. Mar. Environ. Res. 67, 75-82.

Caçador, I., Vale, C., Catarino, F., 1996. Accumulation of $\mathrm{Zn}, \mathrm{Pb}, \mathrm{Cu}, \mathrm{Cr}$ and $\mathrm{Ni}$ in Sediments Between Roots of the Tagus Estuary Salt Marshes, Portugal. Estuar. Coast. Shelf Sci. 42, 393-403.

Caetano, M., Falcao, M., Vale, C., Bebianno, M.J., 1997. Tidal flushing of ammonium, iron and manganese from inter-tidal sediment pore waters. Mar. Chem. 58, 203-211. 
Caetano, M., Fonseca, N., Cesário Carlos Vale, R., 2007. Mobility of Pb in salt marshes recorded by total content and stable isotopic signature. Sci. Total Environ. 380, 84-92.

Caetano, M., Vale, C., 2002. Retention of arsenic and phosphorus in iron-rich concretions of Tagus salt marshes. Mar. Chem. 79, 261-271.

Caetano, M., Vale, C., Cesário, R., Fonseca, N., 2008. Evidence for preferential depths of metal retention in roots of salt marsh plants. Sci. Total Environ. 390, 466-474.

Cobelo-García, A., López-Sánchez, D.E., Almécija, C., Santos-Echeandia, J., 2013. Behaviour of Platinum During Estuarine Mixing (Pontevedra Ria, NW Iberian Peninsula). Mar. Chem. 150, 11-18.

Cobelo-García, A., Neira, P., Mil-Homens, M., Caetano, M., 2011. Evaluation of the contamination of platinum in estuarine and coastal sediments (Tagus Estuary and Prodelta, Portugal). Mar. Pollut. Bull. 62, 646-650.

Colodner, D., 1991. The marine geochemistry of rhenium, iridium and platinum. PhD Thesis, Massachusetts Institute of Technology.

Colodner, D.C., Boyle, E.A., Edmond, J.M., Thomson, J., 1992. Post-depositional mobility of platinum, iridium and rhenium in marine sediments. Nature 358, 402-404.

Colombo, C., Oates, C.J., Monhemius, A.J., Plant, J.A., 2008. Complexation of platinum, palladium and rhodium with inorganic ligands in the environment. Geochem. Explor. Environ. Anal. 8, 91-101.

Cosden, J.M., Schijf, J., Byrne, R.H., 2003. Fractionation of platinum group elements in aqueous systems: Comparative kinetics of palladium and platinum removal from seawater by Ulva lactuca L. Environ. Sci. Technol. 37, 555-560.

Duarte, B., Caetano, M., Almeida, P.R., Vale, C., Caçador, I., 2010. Accumulation and biological cycling of heavy metal in four salt marsh species, from Tagus estuary (Portugal). Environ. Pollut. 158, 1661-1668.

Fragnière, C., Haldimann, M., Eastgate, A., Krähenbühl, U., 2005. A direct ultratrace determination of platinum in environmental, food and biological samples by ICP-SFMS using a desolvation system. J. Anal. At. Spectrom. 20, 626-630.

Fritsche, J., Meisel, T., 2004. Determination of anthropogenic input of Ru, Rh, Pd, Re, Os, Ir and $\mathrm{Pt}$ in soils along Austrian motorways by isotope dilution ICP-MS. Sci. Total Environ. 325, 145-154.

González-Alcaraz, M.N., Conesa, H.M., del Carmen Tercero, M., Schulin, R., Álvarez-Rogel, J., Egea, C., 2011. The combined use of liming and Sarcocornia fruticosa development for phytomanagement of salt marsh soils polluted by mine wastes. J. Hazard. Mater. $186,805-813$.

Halbach, P., Kriete, C., Prause, B., Puteanus, D., 1989. Mechanisms to explain the platinum concentration in ferromanganese seamount crusts. Chem. Geol. 76, 95-106.

Haus, N., Zimmermann, S., Wiegand, J., Sures, B., 2007. Occurrence of platinum and additional traffic related heavy metals in sediments and biota. Chemosphere 66, 619-629.

Hein, J.R., Koschinsky, A., 2014. 13.11 - Deep-Ocean Ferromanganese Crusts and Nodules, in: Heinrich, D.H., Turekian, K.K. (Eds.), Treatise on Geochemistry (Second Edition). Elsevier, Oxford, pp. 273-291.

Hein, J.R., Koschinsky, A., Bau, M., Manheim, F.T., Kang, J.-K., Roberts, L., 2000. Cobalt-rich Ferromagnese crusts in the Pacific, in: Cronan, D.S. (Ed.), Handbook of Marine Mineral Deposits. CRC Press, pp. 239-280. 
Heiri, O., Lotter, A.F., Lemcke, G., 2001. Loss on ignition as a method for estimating organic and carbonate content in sediments: reproducibility and comparability of results. J. Paleolimnol. 25, 101-110.

Helmers, E., Mergel, N., 1998. Platinum and rhodium in a polluted environment: studying the emissions of automobile catalysts with emphasis on the application of CSV rhodium analysis. Fresenius J. Anal. Chem. 362, 522-528.

Hodge, V., Stallard, M., Koide, M., Goldberg, E.D., 1986. Determination of platinum and iridium in marine waters, sediments, and organisms. Anal. Chem. 58, 616-620.

Hoppstock, K., Alt, F., Cammann, K., Weber, G., 1989. Determination of platinum in biotic and environmental materials Part II: A sensitive voltammetric method. Fresenius Z. Für Anal. Chem. 335, 813-816.

Institute of Reference Materials and Measurements, 2013. Certified Reference Material 2013. irmm.jrc.ec.europa.eu/.

Instituto de Intraestructuras Rodoviárias IP (Portugal), 2013. Relatório de Tráfego na rede nacional de auto-estradas $3^{\circ}$ Trimestre de 2013.

Johnson Matthey, 2013. Market Data Tables. www.platinum.matthey.com.

Koschinsky, A., Hein, J.R., 2003. Uptake of elements from seawater by ferromanganese crusts: solid-phase associations and seawater speciation. Mar. Geol. 198, 331-351.

Kubrakova, I.V., Fortygin, A.V., Lobov, S.G., Koshcheeva, I.Y., Tyutyunnik, O.A., Mironenko, M.V., 2011. Migration of platinum, palladium, and gold in the water systems of platinum deposits. Geochem. Int. 49, 1072-1084.

Lorand, J.-P., Luguet, A., Alard, O., 2008. Platinum-group elements: a new set of key tracers for the Earth's interior. Elements 4, 247-252.

Lustig, S., Zang, S., Michalke, B., Schramel, P., Beck, W., 1997. Platinum determination in nutrient plants by inductively coupled plasma mass spectrometry with special respect to the hafnium oxide interference. Fresenius J. Anal. Chem. 357, 1157-1163.

Madureira, M.J.M., 1997. Biogeoquímica do enxofre em sedimentos de Sapais: efeitos na química do ferro e do manganês. PhD Thesis, Universidade Técnica de Lisboa.

Mil-Homens, M., Caetano, M., Costa, A.M., Lebreiro, S., Richter, T., de Stigter, H., Trancoso, M.A., Brito, P., 2013. Temporal evolution of lead isotope ratios in sediments of the Central Portuguese Margin: A fingerprint of human activities. Mar. Pollut. Bull. 74, 274-284.

Moldovan, M., Rauch, S., Gómez, M., Antonia Palacios, M., Morrison, G.M., 2001. Bioaccumulation of palladium, platinum and rhodium from urban particulates and sediments by the freshwater isopod Asellus aquaticus. Water Res. 35, 4175-4183.

National Researcher council Canada, 2013. Marine sediment reference materials for trace metals and other constituents. www.nrc-cnrc.gc.ca/index.html

Neira, P., Cobelo-García, A., Besada, V., Santos-Echeandía, J., Bellas, J., 2015. Evidence of increased anthropogenic emissions of platinum: Time-series analysis of mussels (19912011) of an urban beach. Sci. Total Environ. 514, 366-370.

Obata, H., Yoshida, T., Ogawa, H., 2006. Determination of picomolar levels of platinum in estuarine waters: A comparison of cathodic stripping voltammetry and isotope dilutioninductively coupled plasma mass spectrometry. Anal. Chim. Acta 580, 32-38.

Orecchio, S., Amorello, D., 2010. Platinum and rhodium associated with the leaves of Nerium oleander L.; analytical method using voltammetry; assessment of air quality in the Palermo (Italy) area. J. Hazard. Mater. 174, 720-727. 
Peucker-Ehrenbrink, B., Jahn, B., 2001. Rhenium-osmium isotope systematics and platinum group element concentrations: Loess and the upper continental crust. Geochem. Geophys. Geosystems 2, 1061.

Pino, A., Alimonti, A., Conti, M.E., Bocca, B., 2010. Iridium, platinum and rhodium baseline concentration in lichens from Tierra del Fuego (South Patagonia, Argentina). J. Environ. Monit. 12, 1857-1863.

Prego, R., Bao, R., Leira, M., Almécija, C., Cobelo-García, A., 2011. Trace elements in sediment cores of a barrier-lagoon Complex (Louro Lagoon, NW Iberian Peninsula). Presented at the Eurolag 2011, Aveiro (Portugal), p. 104.

Rauch, S., Hemond, H.F., Peucker-Ehrenbrink, B., 2004a. Recent changes in platinum group element concentrations and osmium isotopic composition in sediments from an urban lake. Environ. Sci. Technol. 38, 396-402.

Rauch, S., Hemond, H.F., Peucker-Ehrenbrink, B., 2004b. Source characterisation of atmospheric platinum group element deposition into an ombrotrophic peat bog. J. Environ. Monit. 6, 335-343.

Rauch, S., Morrison, G.M., 2008. Environmental relevance of the platinum-group elements. Elements 4, 259-263.

Rauch, S., Morrison, G.M., 1999. Platinum uptake by the freshwater isopod Asellus Aquaticus in urban rivers. Sci. Total Environ. 235, 261-268.

Ravindra, K., Bencs, L., Van Grieken, R., 2004. Platinum group elements in the environment and their health risk. Sci. Total Environ. 318, 1-43.

Reith, F., Campbell, S.G., Ball, A.S., Pring, A., Southam, G., 2014. Platinum in Earth surface environments. Earth-Sci. Rev. 131, 1-21.

Sageman, B.B., Lyons, T.W., 2003. Geochemistry of Fine-grained Sediments and Sedimentary Rocks, in: Heinrich, D.H., Turekian, K.K. (Eds.), Treatise on Geochemistry. Pergamon, Oxford, pp. 115-158.

Santos-Echeandía, J., Vale, C., Caetano, M., Pereira, P., Prego, R., 2010. Effect of tidal flooding on metal distribution in pore waters of marsh sediments and its transport to water column (Tagus estuary, Portugal). Mar. Environ. Res. 70, 358-367.

Schäfer, J., Hannker, D., Eckhardt, J.-D., Stüben, D., 1998. Uptake of traffic-related heavy metals and platinum group elements (PGE) by plants. Sci. Total Environ. 215, 59-67.

Schäfer, J., Puchelt, H., 1998. Platinum-Group-Metals (PGM) emitted from automobile catalytic converters and their distribution in roadside soils. J. Geochem. Explor. 64, 307-314.

Sen, I.S., Peucker-Ehrenbrink, B., Geboy, N., 2013. Complex Anthropogenic Sources of Platinum Group Elements in Aerosols on Cape Cod, USA. Environ. Sci. Technol. 47, 10188-10196.

Soyol-Erdene, T.-O., Huh, Y., Hong, S., Hur, S.D., 2011. A 50-year record of platinum, iridium, and rhodium in Antarctic snow: volcanic and anthropogenic sources. Environ. Sci. Technol. 45, 5929-5935.

Sundby, B., Caetano, M., Vale, C., Gobeil, C., Luther, G.W., Nuzzio, D.B., 2005. Root-induced cycling of lead in salt marsh sediments. Environ. Sci. Technol. 39, 2080-2086.

Sundby, B., Vale, C., Caçador, Z., Catarino, F., Madureira, M.-J., Caetano, M., 1998. Metal-rich concretions on the roots of salt marsh plants: Mechanism and rate of formation. Limnol. Oceanogr. 43, 245-252.

Sundby, B., Vale, C., Caetano, M., Luther Iii, G.W., 2003. Redox chemistry in the root zone of a salt marsh sediment in the Tagus Estuary, Portugal. Aquat. Geochem. 9, 257-271. 
Sutherland, R.A., Pearson, D.G., Ottley, C.J., 2007. Platinum-group elements (Ir, Pd, Pt and Rh) in road-deposited sediments in two urban watersheds, Hawaii. Appl. Geochem. 22, $1485-1501$.

Tanackovic, S.L., Caetano, M., Vale, C., 2008. Effect of salt-marsh plants on the mobility of Cr in sediments. Cienc. Mar. 34, 363-372.

Tuit, C.B., Ravizza, G.E., Bothner, M.H., 2000. Anthropogenic platinum and palladium in the sediments of Boston Harbor. Environ. Sci. Technol. 34, 927-932.

Turetta, C., Cozzi, G., Varga, A., Barbante, C., Capodaglio, G., Cescon, P., 2003. Platinum group elements determination in seawater by ICP-SFMS: Initial results, in: Journal de Physique IV (Proceedings). pp. 1321-1324.

Vale, C., 1990. Temporal variations of particulate metals in the Tagus River Estuary. Sci. Total Environ. 97, 137-154.

Vale, C., Caetano, M., Raimundo, J., 2003. Incorporation of trace elements on iron-rich concretions around plant roots of Tagus estuary salt marsh (Portugal). J. Soils Sediments 3, 208-212.

Vale, C., Canário, J., Caetano, M., Lavrado, J., Brito, P., 2008. Estimation of the anthropogenic fraction of elements in surface sediments of the Tagus Estuary (Portugal). Mar. Pollut. Bull. 56, 1364-1367.

Valentim, J.M., Vaz, N., Silva, H., Duarte, B., Caçador, I., Dias, J.M., 2013. Tagus estuary and Ria de Aveiro salt marsh dynamics and the impact of sea level rise. Estuar. Coast. Shelf Sci. 130, 138-151.

van den Berg, C.M.G., Jacinto, G.S., 1988. The determination of platinum in sea water by adsorptive cathodic stripping voltammetry. Anal. Chim. Acta 211, 129-139.

Wei, C., Morrison, G.M., 1994. Platinum analysis and speciation in urban gullypots. Anal. Chim. Acta 284, 587-592.

Whiteley, J.D., Murray, F., 2005. Autocatalyst-derived platinum, palladium and rhodium (PGE) in infiltration basin and wetland sediments receiving urban runoff. Sci. Total Environ. 341, 199-209.

Windom, H.L., Schropp, S.J., Calder, F.D., Ryan, J.D., Smith Jr, R.G., Burney, L.C., Lewis, F.G., Rawlinson, C.H., 1989. Natural trace metal concentrations in estuarine and coastal marine sediments of the southeastern United States. Environ. Sci. Technol. 23, 314320.

Zereini, F., Skerstupp, B., Rankenburg, K., Dirksen, F., Beyer, J.-M., Claus, T., Urban, H., 2001. Anthropogenic emission of platinum-group elements into the environment. J. Soils Sediments 1, 44-49.

Zimmermann, S., Baumann, U., Taraschewski, H., Sures, B., 2004. Accumulation and distribution of platinum and rhodium in the European eel Anguilla anguilla following aqueous exposure to metal salts. Environ. Pollut. 127, 195-202.

Zimmermann, S., Sures, B., 2004. Significance of platinum group metals emitted from automobile exhaust gas converters for the biosphere. Environ. Sci. Pollut. Res. 11, 194199. 
Figure 1: Map of the study area in the Tagus Estuary (Lisbon, SW Europe). Two sampling points were chosen: (A) High Traffic Station (Samouco), under a motorway highway bridge; and (B) Low Traffic Station (Rosario).

Figure 2: Scheme of sampling, pre-treatment and analysis of samples: AdCSV= adsorptive cathodic stripping voltammetry; $\mathrm{AAS}=$ atomic absorption spectrometry; $\mathrm{UV}=$ ultraviolet radiation; $\mathrm{RSS}_{\mathrm{T}}=$ total reduced sulfur species

Figure 3: Profiles of dissolved $\mathrm{O}_{2}(\%)$ and $\mathrm{Eh}\left(\mathrm{mV}\right.$ vs. $\left.\mathrm{H}^{+}\right)$in the unvegetated (left column) and vegetated (middle column) cores of High Traffic Station and vegetated cores of Low Traffic Station (right column) for spring (upper panel) and summer (Lower panel).

Figure 4: Profiles of biomass (\%) and LOI (loss on ignition, \%) in the unvegetated (left column) and vegetated (middle column) cores of High Traffic Station and vegetated cores of Low Traffic Station (right column) for spring (upper panel) and summer (Lower panel).

Figure 5: Profiles of dissolved Fe $\left(\mathrm{mg} \mathrm{L}^{-1}\right), \mathrm{Mn}\left(\mathrm{mg} \mathrm{L}^{-1}\right)$ and $\mathrm{RSS}_{\mathrm{T}}$ (total reduced sulfur species, $\mu \mathrm{g} \mathrm{L}^{-1}$ ) for interstitial waters in the unvegetated (left column) and vegetated (middle column) cores of High Traffic Station and vegetated cores of Low Traffic Station (right column) for spring (upper panel) and summer (Lower panel).

Figure 6: Profiles of dissolved $\mathrm{Pt}\left(\mathrm{ng} \mathrm{L}^{-1}\right)$ for interstitial waters in the unvegetated (left column) and vegetated (middle column) cores of High Traffic Station and vegetated cores of Low Traffic Station (right column) for spring (upper panel) and summer (Lower panel).

Figure 7: Profiles of Pt concentration in sediments (left side, $\mathrm{ng} \mathrm{g}^{-1}$ ) and roots (left side, $\mathrm{ng} \mathrm{g}^{-1}$ ) in the unvegetated (left column) and vegetated (middle column) cores of High Traffic Station and vegetated cores of Low Traffic Station (right column) for spring (upper panel) and summer (Lower panel).

Figure 8: Correlation between the Pt solid-water partition coefficient (Kd) and dissolved $\mathrm{Mn}$ in interstitial waters at both sampling stations and seasons (triangles $=$ High Traffic Station unvegetated, diamonds= High Traffic Station vegetated, dots= Low Traffic Station vegetated; black symbol $=$ spring, white symbol $=$ summer; HTS $=$ High Traffic Station, LTS $=$ Low Traffic Station). Relationship is statistically significant $(\mathrm{p}<0.05)$. Data corresponding to $0-4 \mathrm{cms}$, where anthropogenic Pt is settled, are not used for the correlations.

Figure 9: Seasonal cycle of precipitation and dissolution of natural $\mathrm{Pt}$ in vegetated sediments from salt marshes, controlled by plants action, organic matter degradation and the chemistry of Fe-Mn.

Figure 10: Enrichment factor in the concentration of some elements in roots of Sarcocornia fruticosa respect of their concentration in sediments $\left([\mathrm{m}]_{\text {roots }} /[\mathrm{m}]_{\text {sediment }}\right)$. Values bellow the horizontal line indicate a depletion in roots and values above the horizontal line indicate an enrichment. 
Figure 11: Correlation between dissolved Pt in interstitial water and concentrations in roots for High Traffic Station (left) and Low Traffic Station (right) in spring (black) and summer (white). Datapoints in brackets (peaks is interstitial water) are outliers not used for correlation calculations. Both relations are statistically significant $(\mathrm{p}<0.05)$. 
Table 1: Values of the auxiliary parameters measured in High Traffic Station and Low Traffic Station during the spring and summer samplings.

\begin{tabular}{|c|c|c|c|c|}
\hline \multirow[t]{2}{*}{ Sampling } & \multirow[t]{2}{*}{ Parameters } & \multicolumn{2}{|c|}{ High Traffic Station } & \multirow{2}{*}{$\begin{array}{c}\text { Low Traffic Sation } \\
\text { Vegetated }\end{array}$} \\
\hline & & Unvegetated & Vegetated & \\
\hline \multirow[t]{4}{*}{ Spring } & $p H$ & $6.60-7.44$ & $6.63-7.07$ & $6.28-6.51$ \\
\hline & $E h$ & . & . & $-74-+316$ \\
\hline & Dissolved $\mathrm{O}_{2}$ & UDL - $2 \%$ & UDL - $20 \%$ & UDL - $18 \%$ \\
\hline & Salinity & $17-34$ & $17-26$ & $22-33$ \\
\hline \multirow[t]{4}{*}{ Summer } & $p H$ & $6.71-7.66$ & $6.24-6.95$ & $5.90-6.41$ \\
\hline & $E h$ & $-66-+210$ & $-94-+180$ & $-52-+340$ \\
\hline & Dissolved $\mathrm{O}_{2}$ & UDL & UDL & UDL $-6.2 \%$ \\
\hline & Salinity & $34-40$ & $35-40$ & $38-50$ \\
\hline
\end{tabular}

UDL $=$ under detection limit 
Table 2: Platinum concentration ( $\mathrm{ng} \mathrm{g}^{-1}$ ) in different tissues of Sarcocornia fruticosa in both sampling stations and seasons and $\mathrm{Pt}$ concentrations in different layers of rizhoconcrections from Low Traffic Station.

\begin{tabular}{|c|c|c|c|c|c|}
\hline \multirow[t]{2}{*}{ Sample } & & \multicolumn{2}{|c|}{$\begin{array}{c}\operatorname{Pt}\left(\mathrm{ng} \mathrm{g}^{-1}\right) \\
\text { High Traffic Station }\end{array}$} & \multicolumn{2}{|c|}{$\begin{array}{c}\text { Pt }\left(\mathrm{ng} \mathrm{g}^{-1}\right) \\
\text { Low Traffic Station }\end{array}$} \\
\hline & & Spring & Summer & Spring & Summer \\
\hline \multirow[t]{3}{*}{ Sarcocornia fruticosa } & Roots & $0.21-1.5$ & $0.027-0.39$ & $0.18-1.6$ & $0.18-1.1$ \\
\hline & Stems & 0.015 & 0.012 & 0.086 & UDL \\
\hline & Leaves & 0.039 & UDL & 0.13 & UDL \\
\hline \multirow[t]{3}{*}{ Rizhoconcrections } & Inner & \multicolumn{2}{|c|}{-} & \multicolumn{2}{|c|}{1.12} \\
\hline & Middle & \multicolumn{2}{|c|}{ - } & \multicolumn{2}{|c|}{0.71} \\
\hline & Outer & \multicolumn{2}{|c|}{ - } & \multicolumn{2}{|c|}{0.87} \\
\hline
\end{tabular}

$\mathrm{UDL}=$ under detection limit 


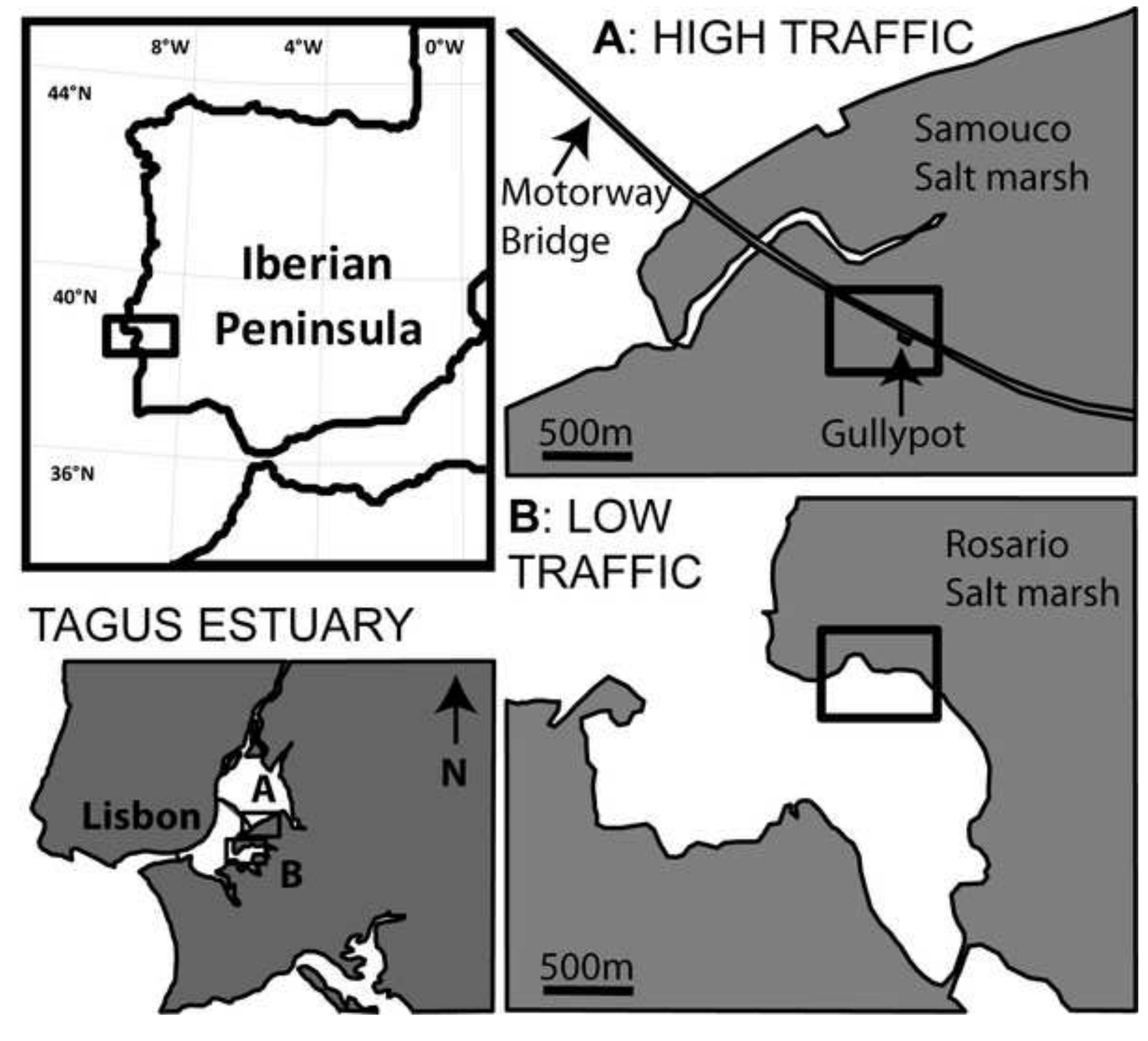

Rosario

Salt marsh . 
Click here to download high resolution image

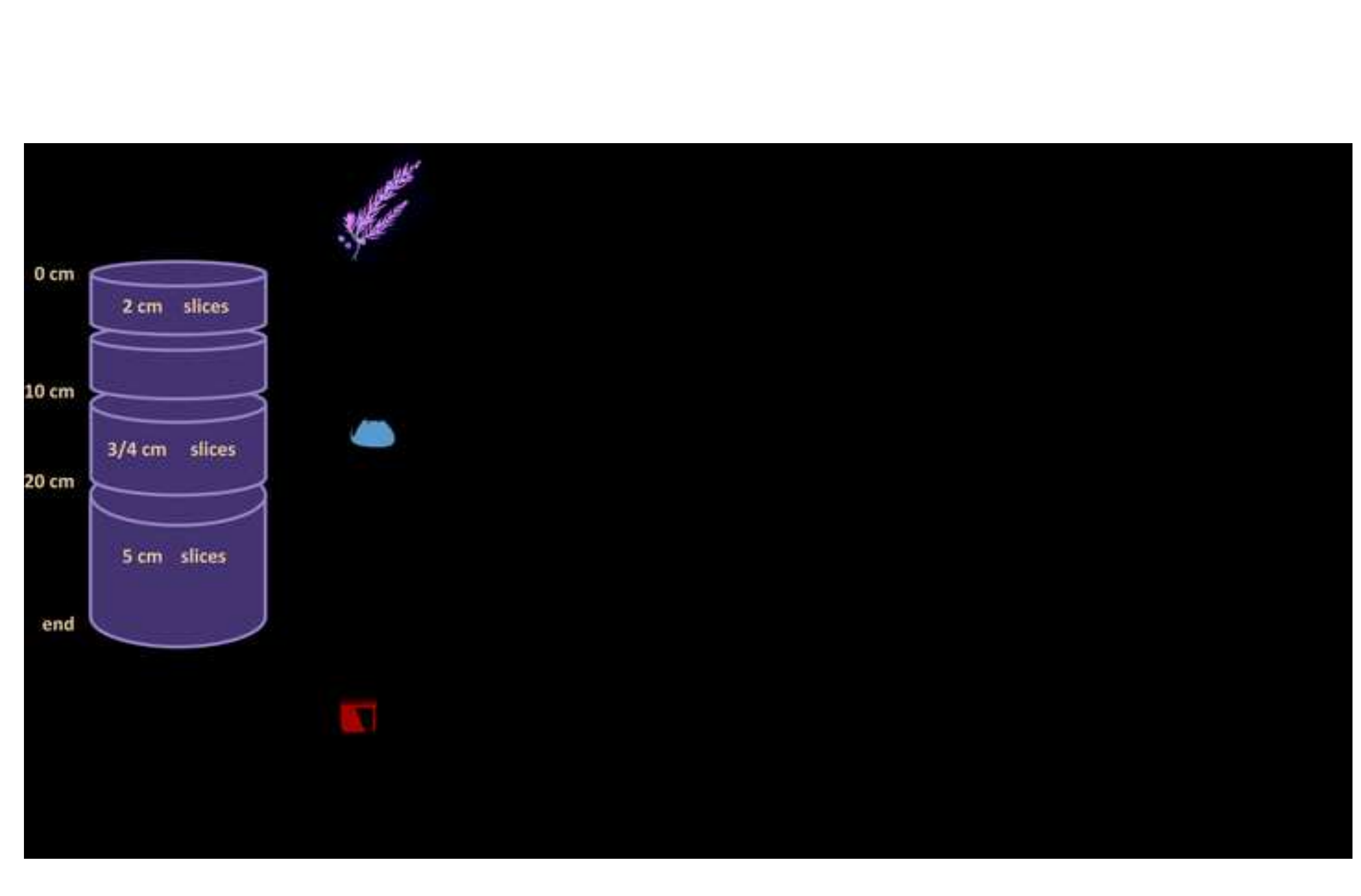




\section{High Traffic Station}

unvegetated

Dissolved oxygen (\%)
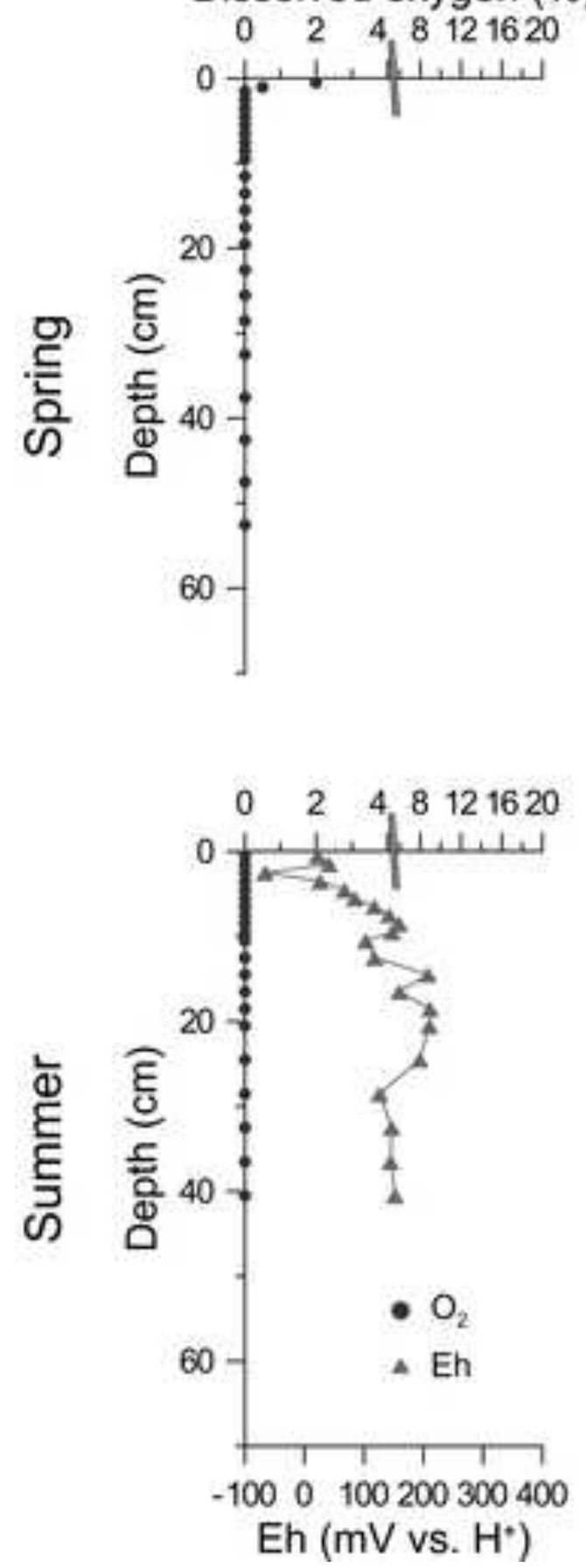

vegetated
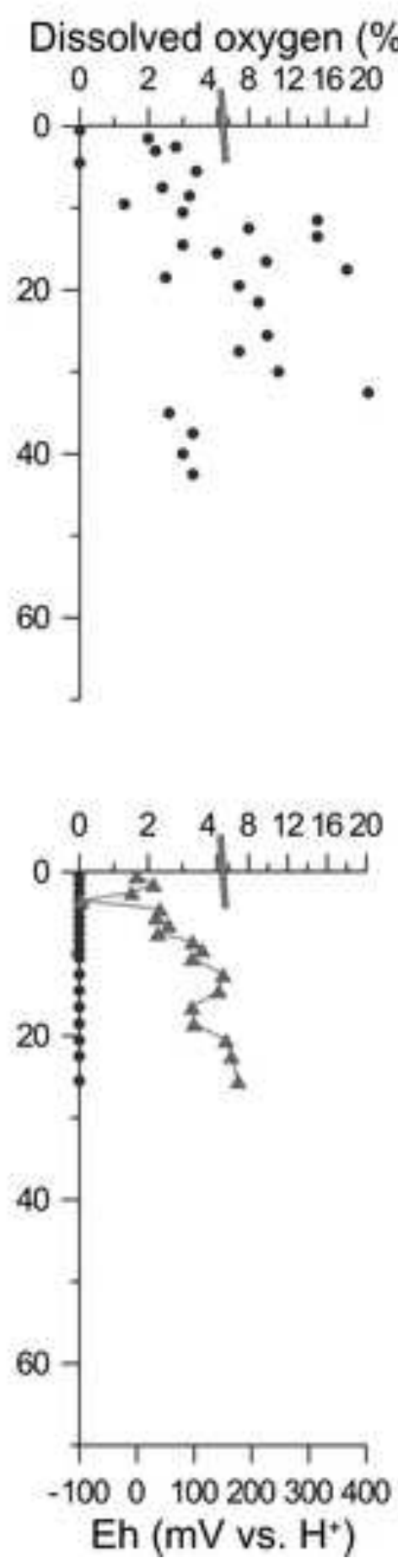

Low Traffic Station

vegetated

Dissolved oxygen (\%)
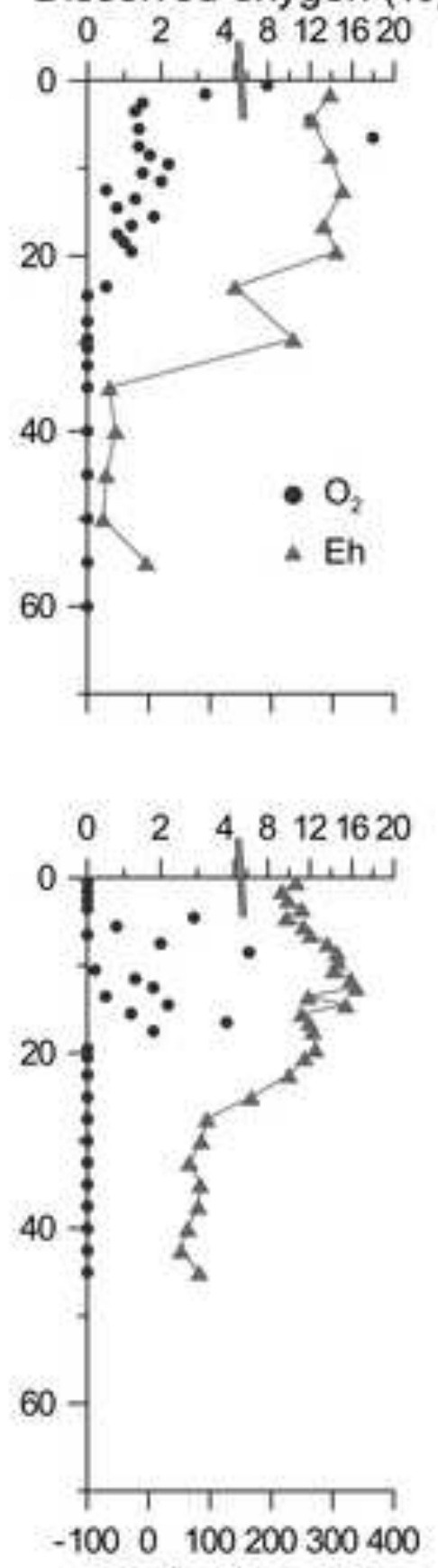

Eh ( $\mathrm{mV}$ vs. $\mathrm{H}^{+}$) 
High Traffic Station

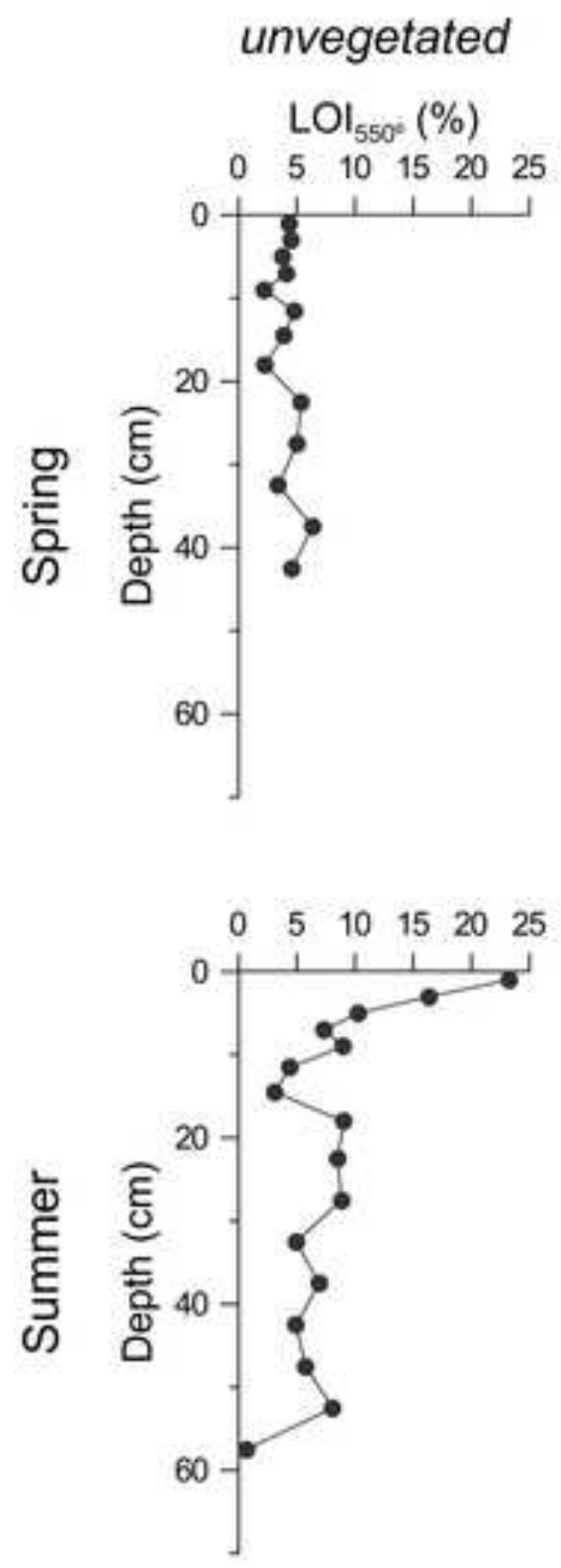

vegetated
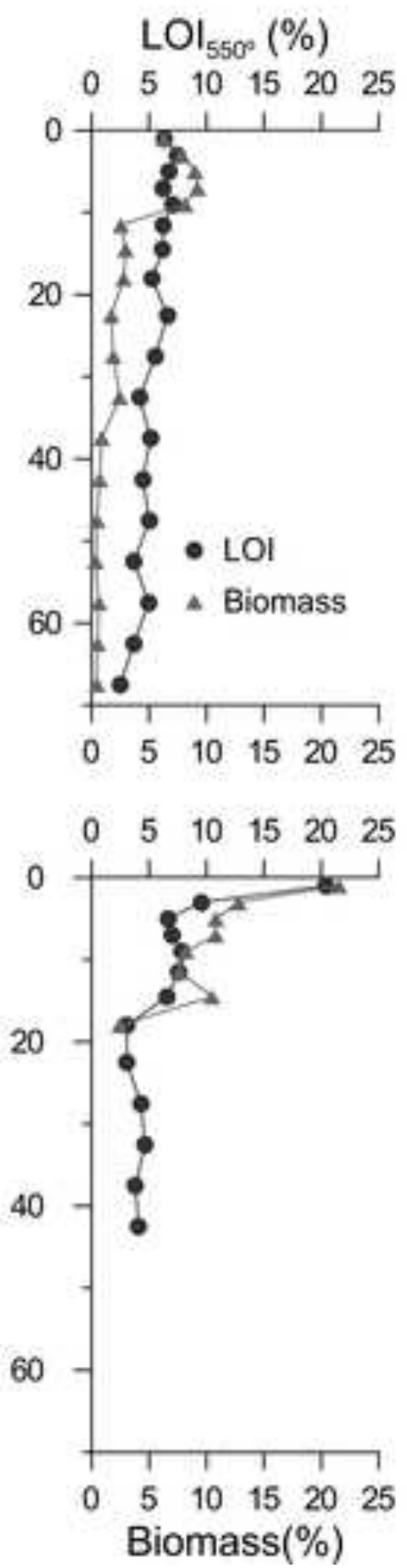

Low Traffic Station

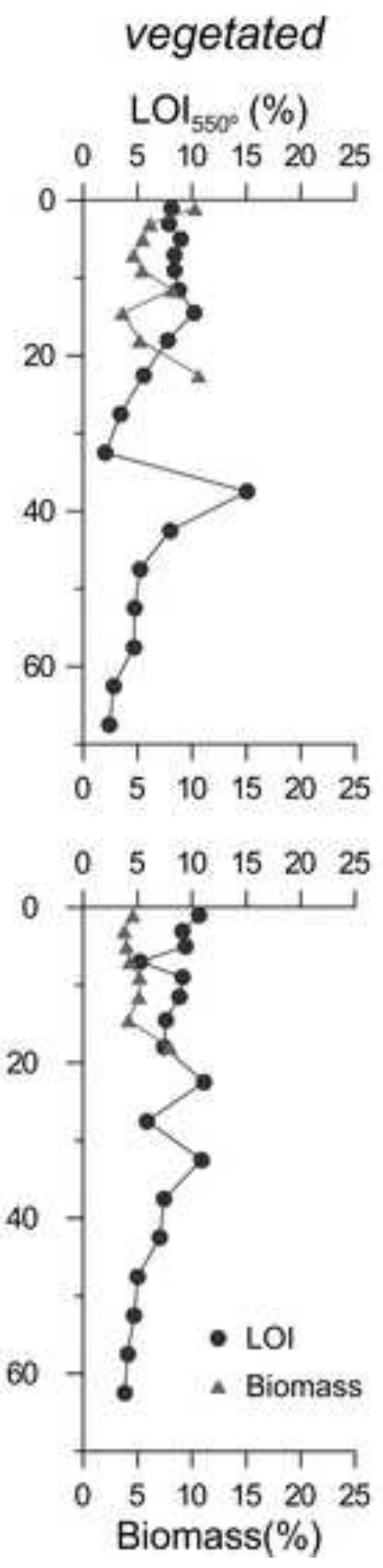


High Traffic Station

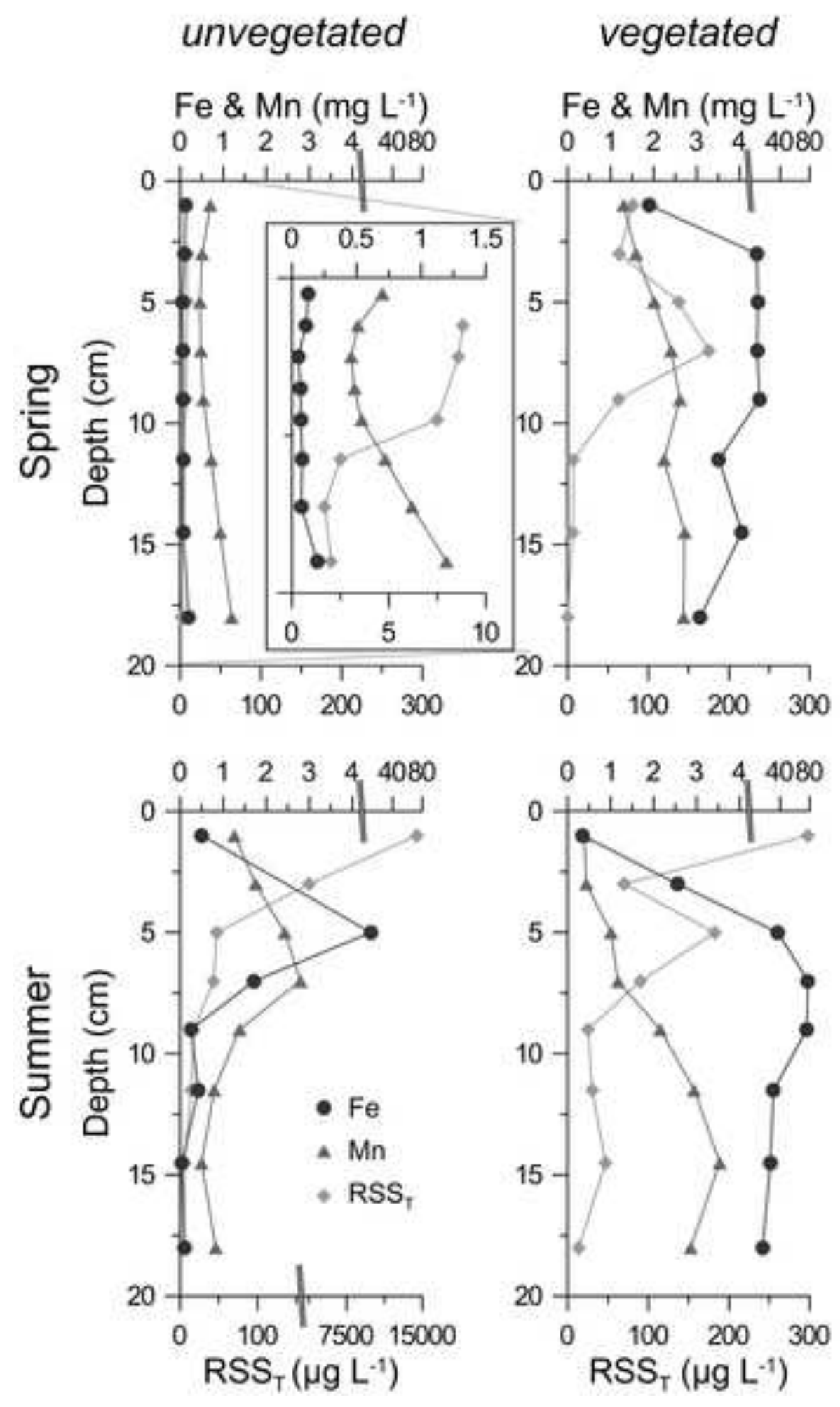

Low Traffic Station

vegetated

$\mathrm{Fe} \& \mathrm{Mn}\left(\mathrm{mg} \mathrm{L}^{-1}\right)$
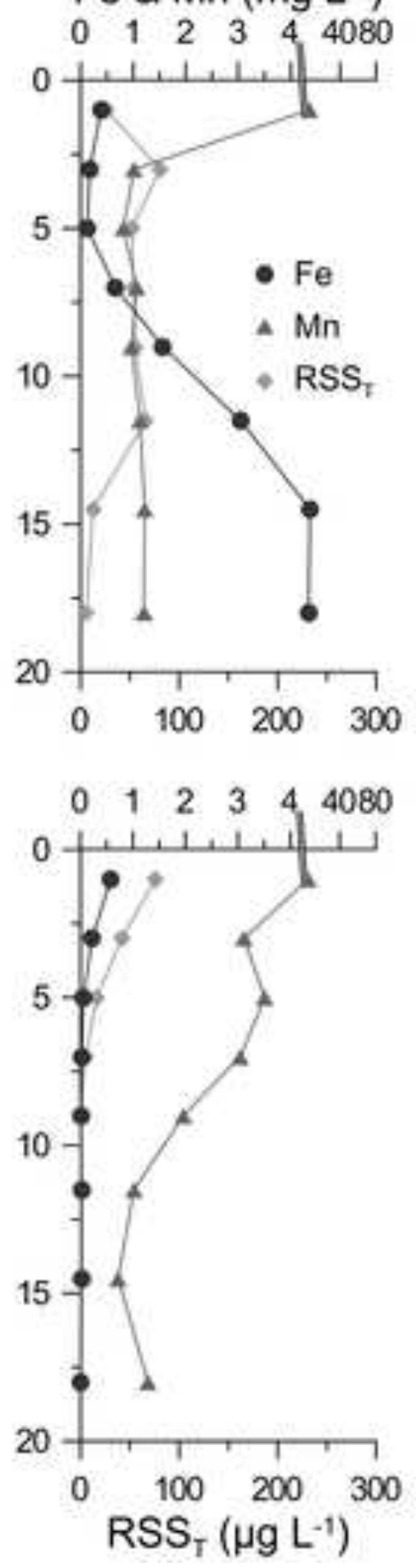


\section{High Traffic Station}

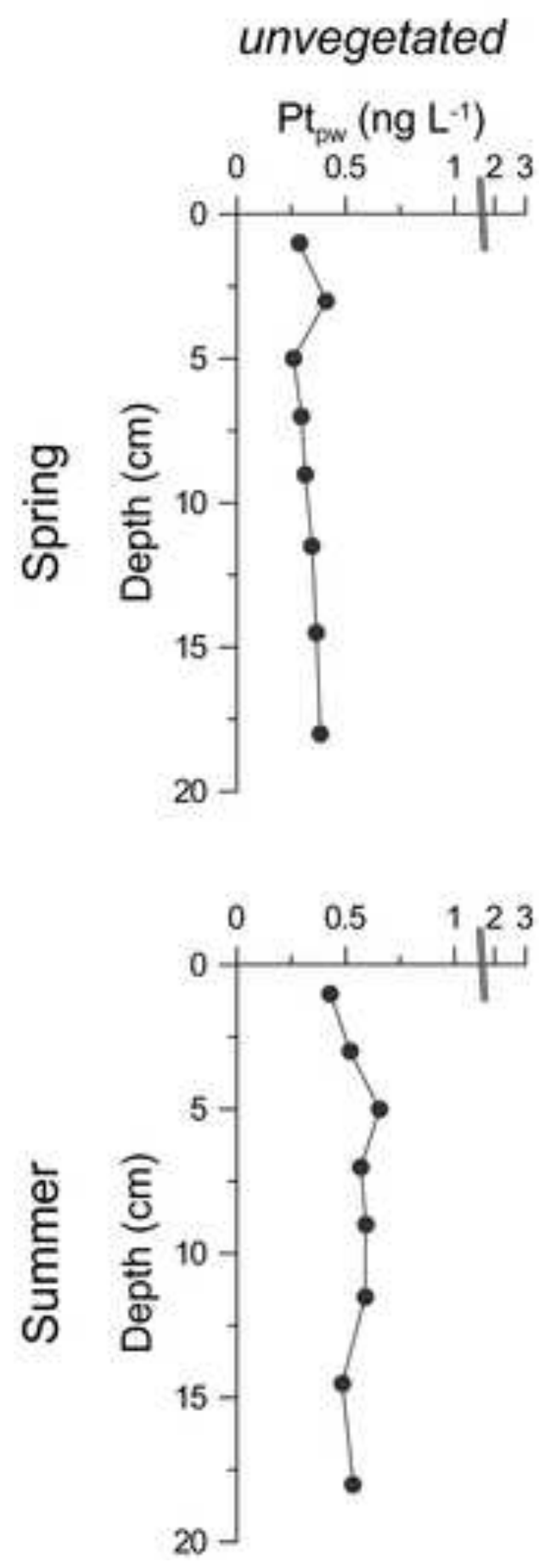

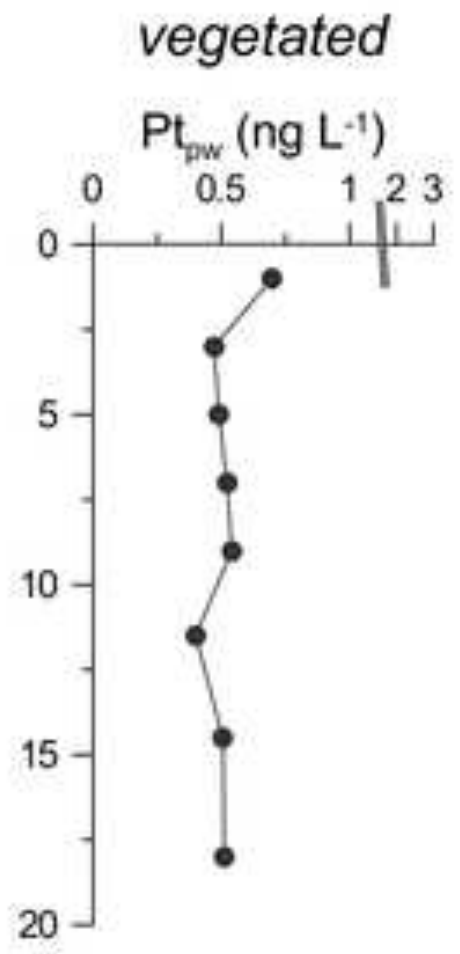

Low Traffic Station
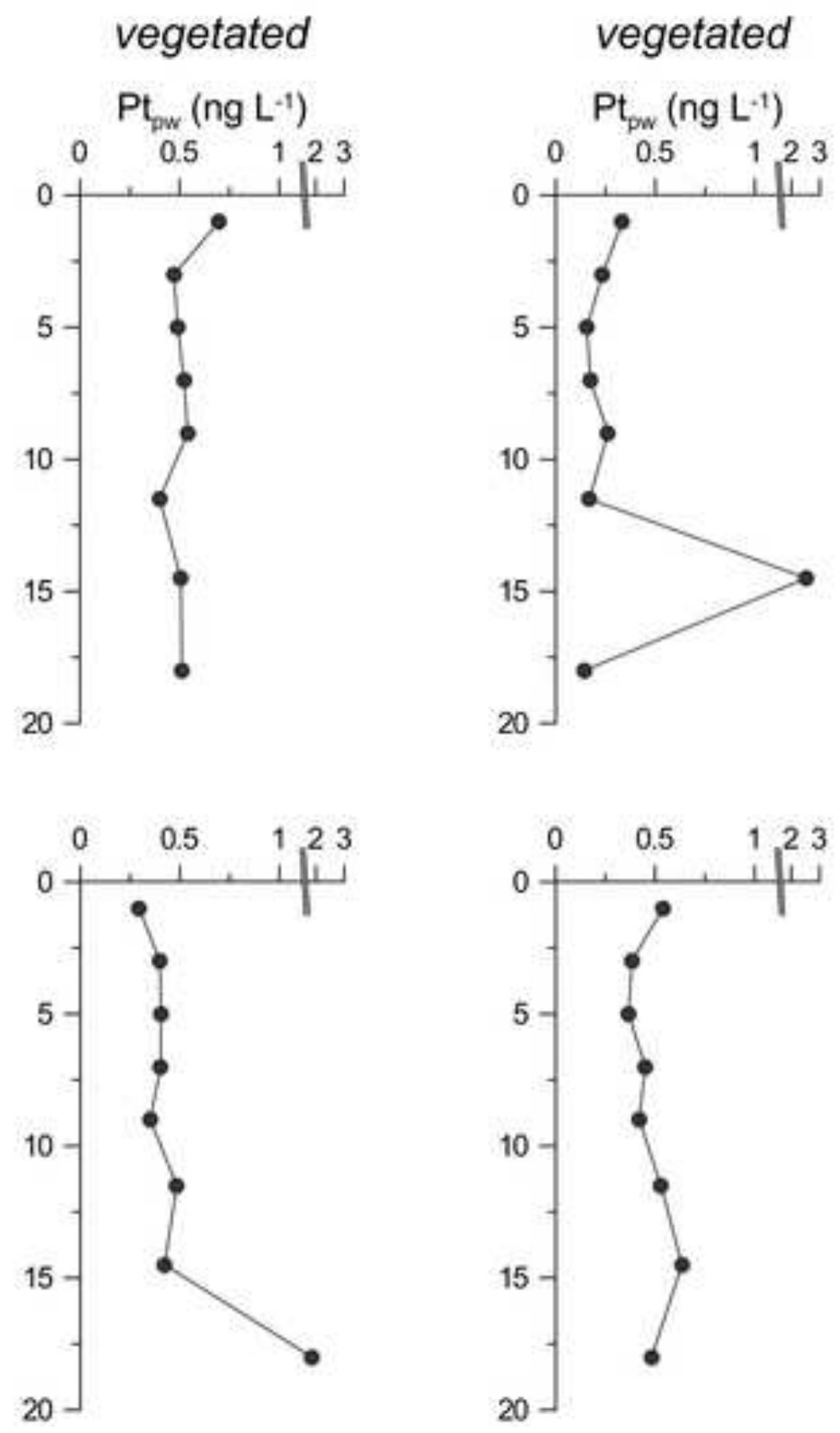
High Traffic Station

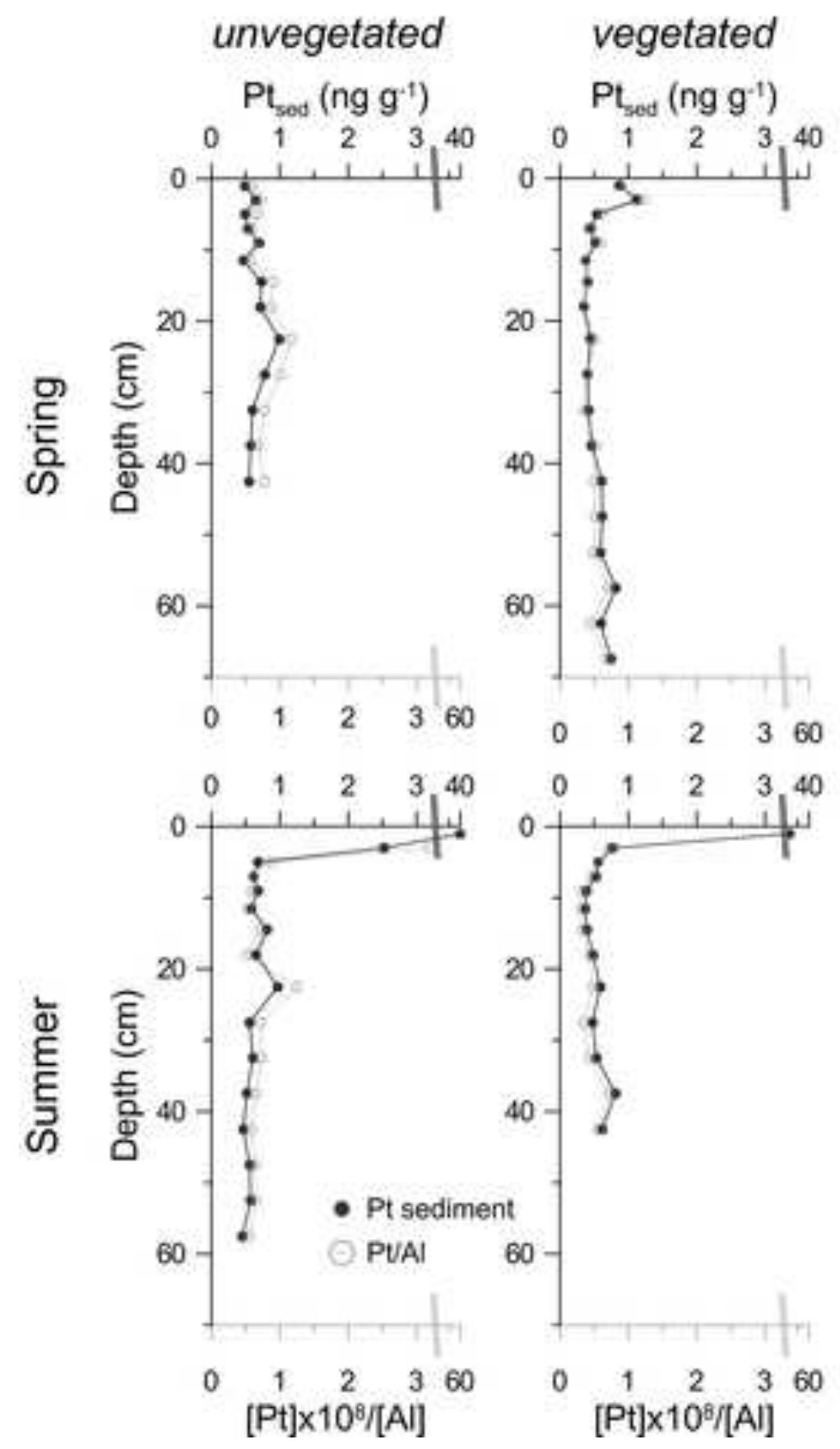

\section{Low Traffic Station High Traffic S Low Traffic S}
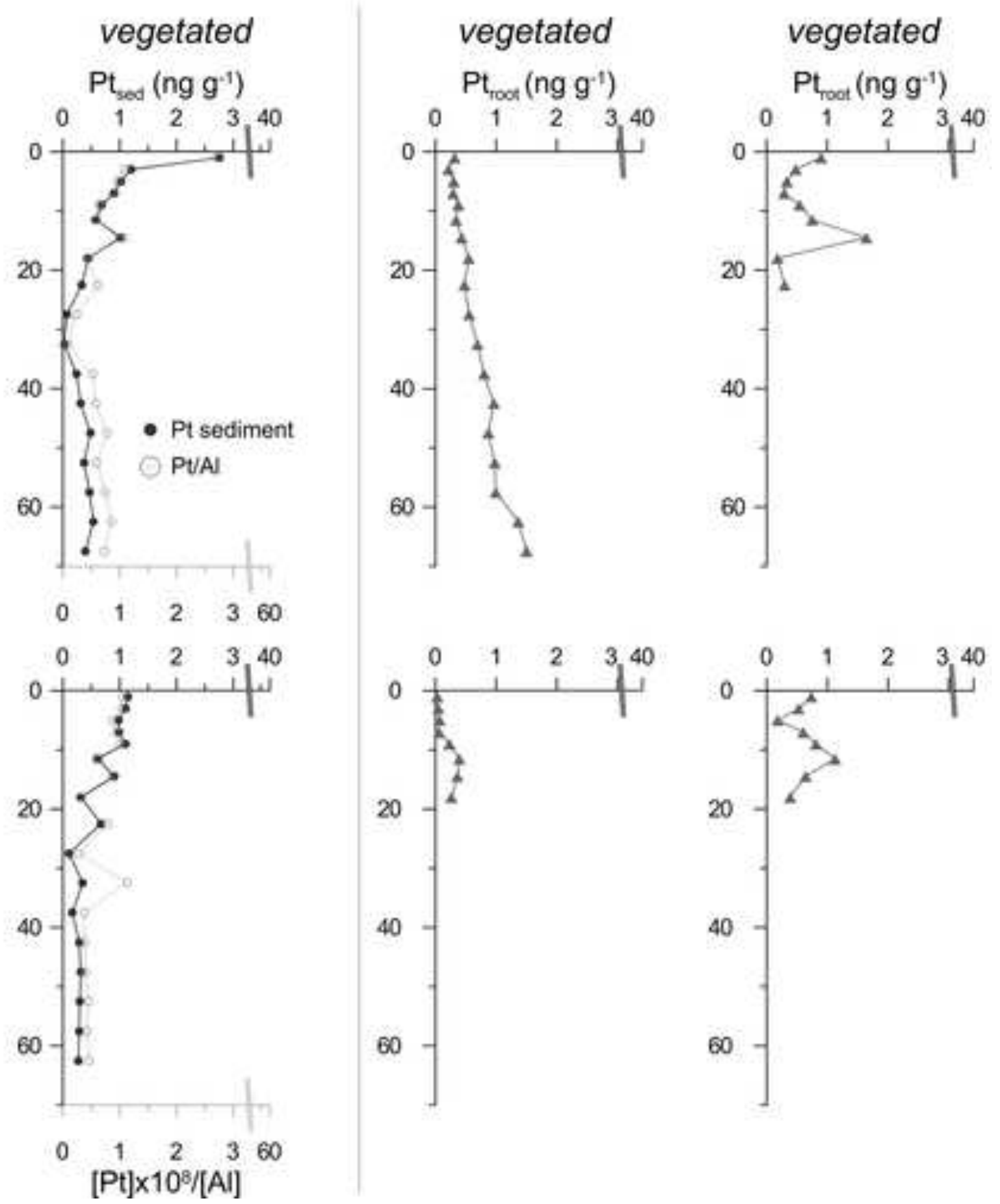


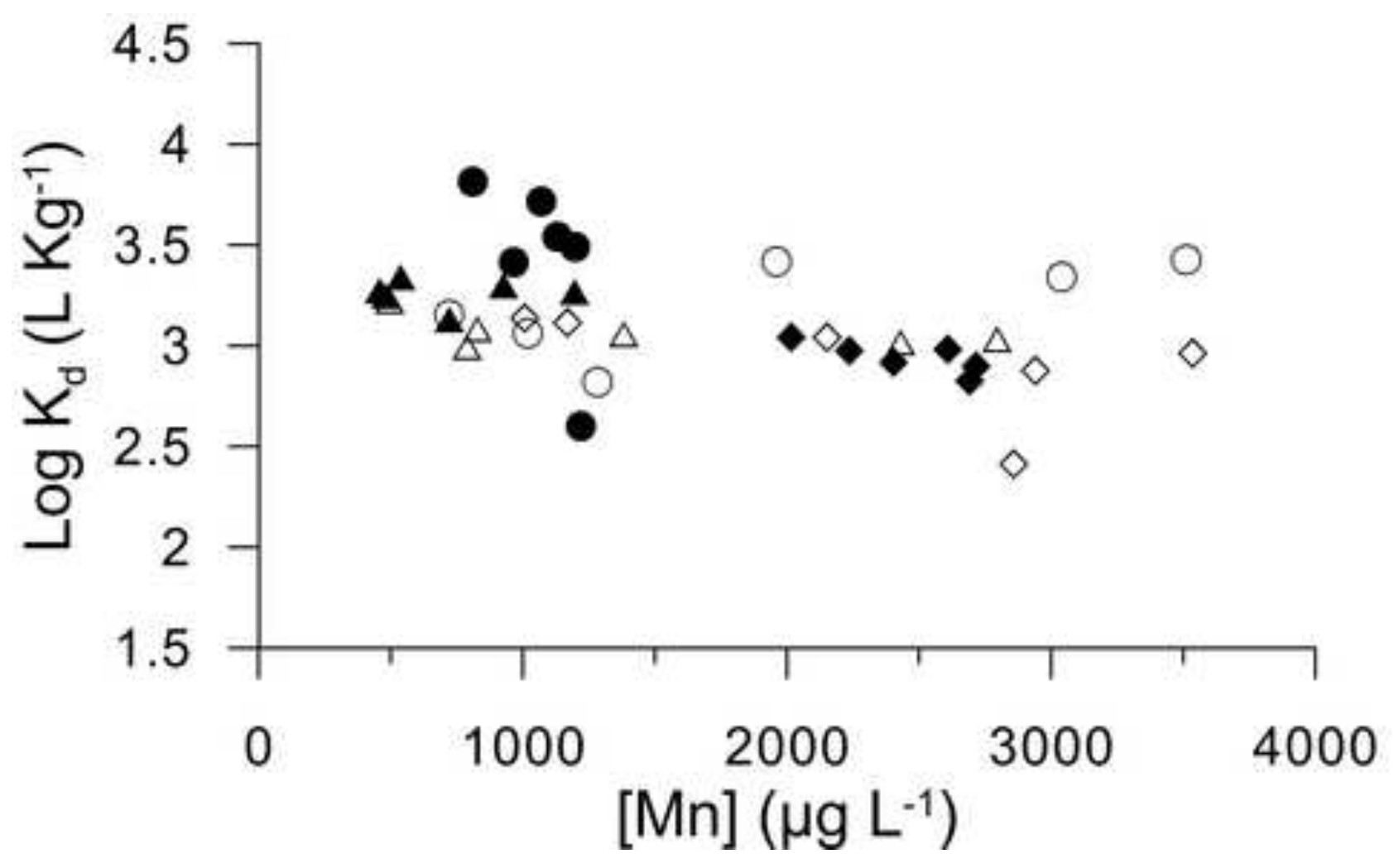

- HTS-unveg spring

$\triangle$ HTS-unveg summer

- HTS-veg spring

$\diamond$ HTS-veg summer

- LTS-veg spring

- LTS-veg summer 
Click here to download high resolution image

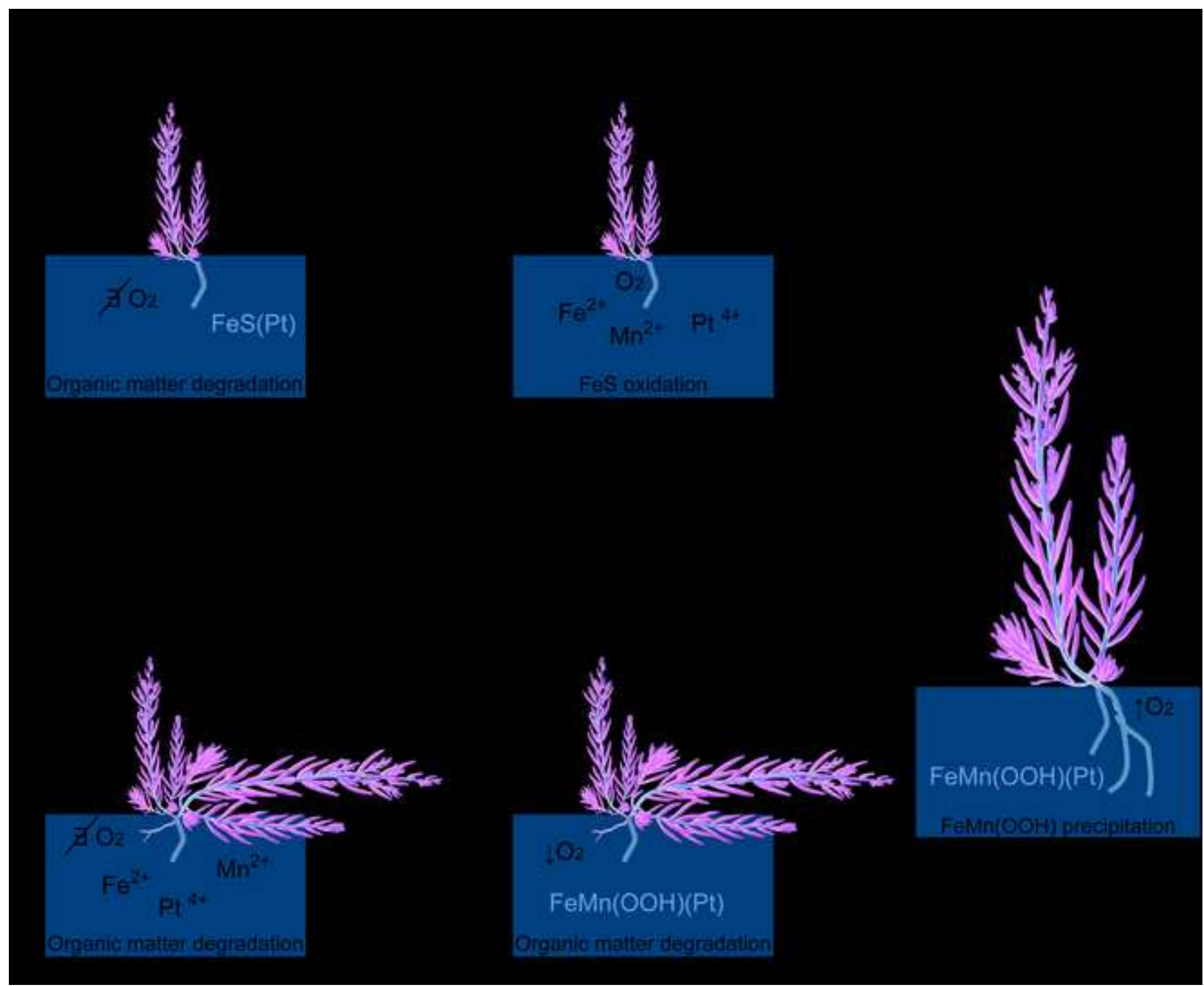

FeMn(OOH)(Pt) 


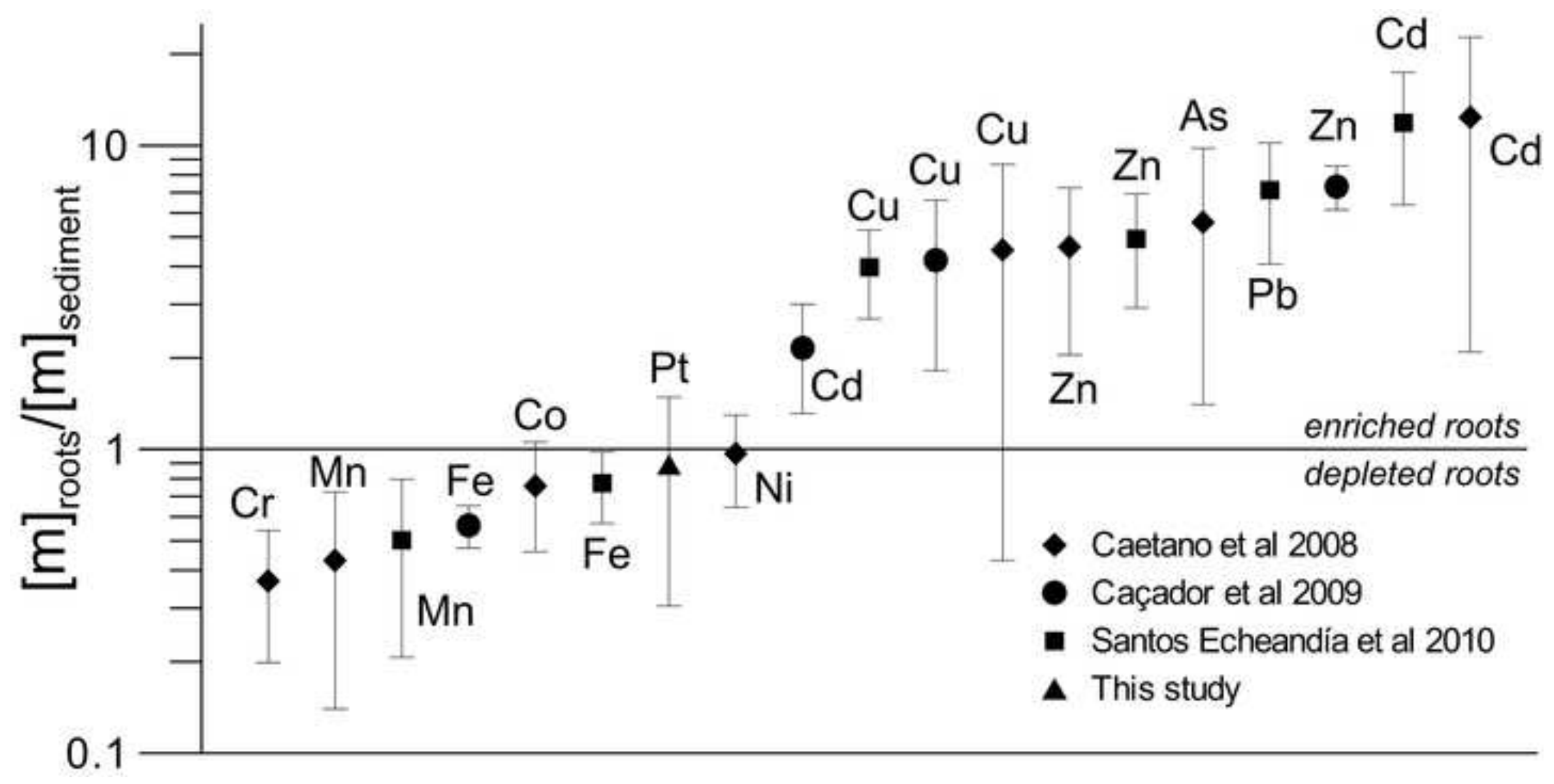



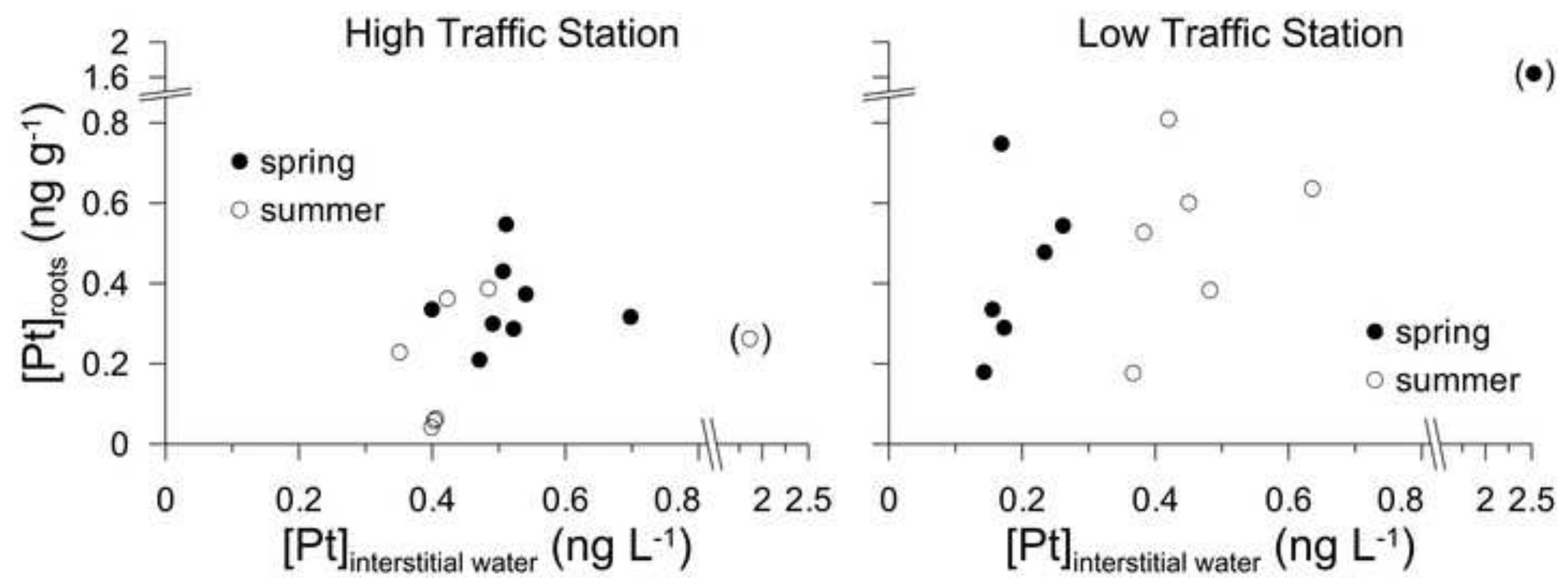

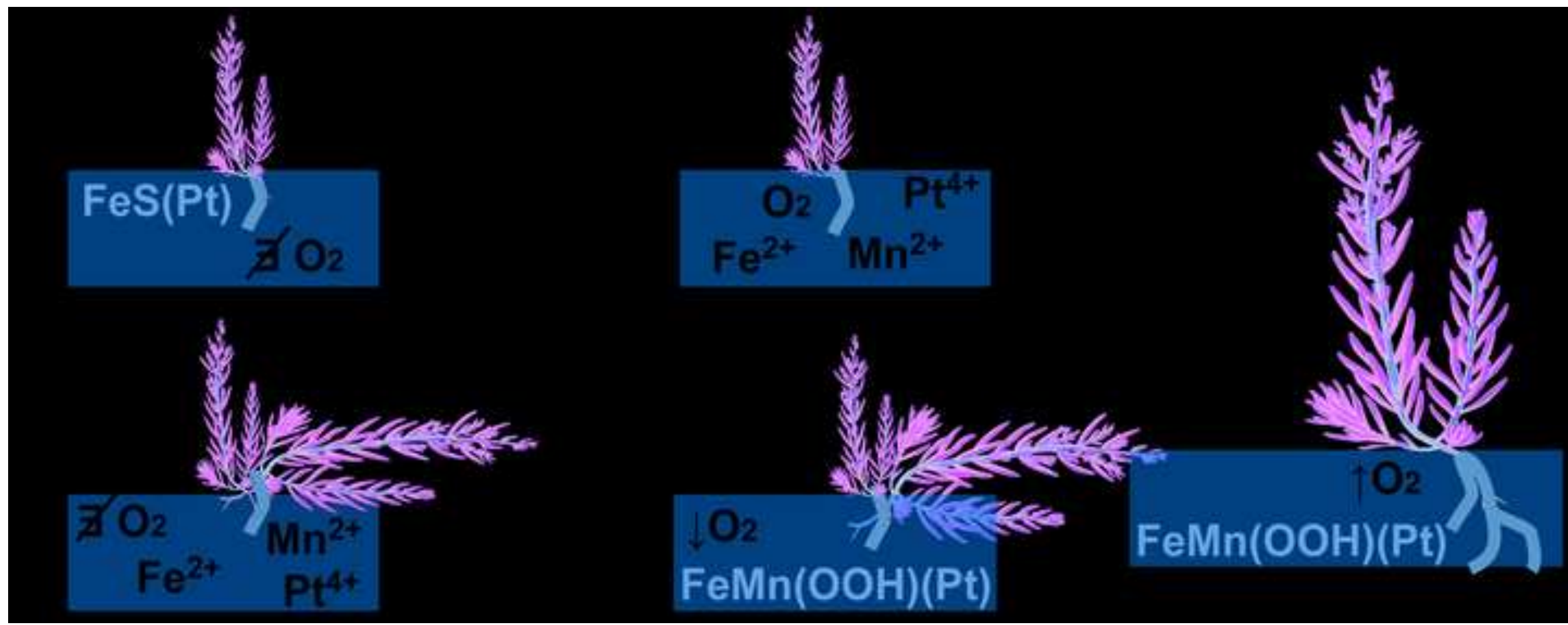


\section{Supporting information 1: Determination of Fe and Mn in sediments}

Iron and $\mathrm{Mn}$ were determined in sediments by electrothermal graphite furnace atomic absorption spectrophotometry (GFAA, Varian SpectrAA 220). Sediment samples were prepared following the method explained for $\mathrm{Al}$-acid digested using a microwave oven (MarsXpress, CEM) in Teflon ${ }^{\circledR}$ bombs using a 3:1 mixture of $\mathrm{HNO}_{3}$ (Hiperpur@ 69\% Panreac) and $\mathrm{HF}$ (Suprapur@ $40 \%$ Merck)-. The accuracy of the analytical methodology was checked using PACS-2 marine sediment reference material, where a recovery of $100 \%$ for $\mathrm{Fe}$ and $\mathrm{Mn}$ were obtained $\left(\right.$ Fe certified value $=41.1 \pm 1.9 \mathrm{~g} \mathrm{~kg}^{-1}$ and Fe measured value $=41.2 \pm 1.6 \mathrm{~g} \mathrm{~kg}^{-1}$; Mn certified value $=440 \pm 19 \mathrm{mg} \mathrm{kg}^{-1}$ and Mn measured value $=449 \pm 44 \mathrm{mg} \mathrm{kg}^{-1}$ ).

Table S-1: Blanks and detection limits (3xSD) for Pt determination in interstitial waters, sediments and roots. Results for the road dust reference material BCR-723 are also included.

\begin{tabular}{lccc}
\hline & Interstitial water $\left(\mathrm{ng} \mathrm{L}^{-1}\right)$ & Sediment $\left(\mathrm{ng} \mathrm{g}^{-1}\right)$ & Roots $\left(\mathrm{ng} \mathrm{g}^{-1}\right)$ \\
\hline Blank & $0.003 \pm 0.003(n=13)$ & $0.024 \pm 0.004(n=10)$ & $0.057 \pm 0.018(n=8)$ \\
Detection Limit & 0.01 & 0.013 & 0.054 \\
Reference Material & - & $81.5 \pm 6.3(n=7)$ & - \\
& & $($ cert. $81.3 \pm 2.5)$ & \\
\hline
\end{tabular}

Values: mean value $\pm \mathrm{SD}$; number of replicates in brackets.

Blanks for Pt correspond to a typical mass of $200 \mathrm{mg}$ of sediment and $100 \mathrm{mg}$ of dried roots. 
Table S-2: Raw data of unvegetated core from High Traffic Station (Samouco Salt Marsh) in Spring (March 2011).

\begin{tabular}{|c|c|c|c|c|c|c|c|c|c|c|c|}
\hline & \multirow[b]{2}{*}{$\begin{array}{c}\text { Depth } \\
(\mathrm{cm})\end{array}$} & \multicolumn{4}{|c|}{ sediment } & \multirow{2}{*}{$\begin{array}{c}\text { roots } \\
\begin{array}{c}\mathrm{Pt} \\
\left(\mathrm{ng} \mathrm{g}^{-1}\right)\end{array}\end{array}$} & \multicolumn{5}{|c|}{ interstitial water } \\
\hline & & $\begin{array}{c}\mathrm{Pt} \\
\left(\mathrm{ng} \mathrm{g}^{-1}\right)\end{array}$ & $\begin{array}{c}\mathrm{Al} \\
\left(\mathrm{mg} \mathrm{g}^{-1}\right)\end{array}$ & $\begin{array}{c}\mathrm{Fe} \\
\left(\mathrm{mg} \mathrm{g}^{-1}\right)\end{array}$ & $\begin{array}{c}\mathrm{Mn} \\
\left(\mu \mathrm{g} \mathrm{g}^{-1}\right)\end{array}$ & & $\begin{array}{c}\mathrm{Pt} \\
\left(\mathrm{ng} \mathrm{L}^{-1}\right)\end{array}$ & $\begin{array}{c}\mathrm{Fe} \\
\left(\mathrm{mg} \mathrm{L}^{-1}\right)\end{array}$ & $\begin{array}{c}\mathrm{Mn} \\
\left(\mathrm{mg} \mathrm{L}^{-1}\right)\end{array}$ & $\begin{array}{c}\mathrm{RSS}_{\mathrm{T}} \\
\left(\mu \mathrm{g} \mathrm{L}^{-1}\right)\end{array}$ & salinity \\
\hline HTS overlying & - & - & - & - & - & - & 1.58 & 0.041 & 0.103 & - & 17 \\
\hline HTS 00-02 & 1 & 0.495 & 83.3 & 49.2 & 468 & - & 0.286 & 0.126 & 0.701 & - & 20 \\
\hline HST 02-04 & 3 & 0.646 & 89.2 & 41.5 & 344 & - & 0.410 & 0.106 & 0.511 & 8.82 & 19 \\
\hline HST 04-06 & 5 & 0.492 & 72.8 & 41.1 & 342 & - & 0.260 & 0.048 & 0.458 & 8.59 & 20 \\
\hline HST 06-08 & 7 & 0.530 & 91.2 & 45.5 & 320 & - & 0.297 & 0.066 & 0.482 & - & 20 \\
\hline HST 08-10 & 9 & 0.689 & 98.1 & 44.3 & 260 & - & 0.313 & 0.067 & 0.538 & 7.50 & 22 \\
\hline HST 10-13 & 11.5 & 0.471 & 84.7 & 43.0 & 276 & - & 0.346 & 0.079 & 0.721 & 2.48 & 24 \\
\hline HST 13-16 & 14.5 & 0.733 & 80.9 & 46.7 & 332 & - & 0.366 & 0.071 & 0.927 & 1.69 & 29 \\
\hline HST 16-20 & 18 & 0.713 & 82.0 & 48.4 & 326 & - & 0.383 & 0.194 & 1.200 & 2.02 & 34 \\
\hline HST 20-25 & 22.5 & 0.992 & 85.2 & 44.2 & 308 & - & - & - & - & - & - \\
\hline HST 25-30 & 27.5 & 0.780 & 77.4 & 44.5 & 262 & - & - & - & - & - & - \\
\hline HST 30-35 & 32.5 & 0.599 & 76.6 & 38.2 & 264 & - & - & - & - & - & - \\
\hline HST 35-40 & 37.5 & 0.576 & 85.0 & 46.0 & 296 & - & - & - & - & - & - \\
\hline HST 40-45 & 42.5 & 0.548 & 69.9 & 41.4 & 292 & - & - & - & - & - & - \\
\hline
\end{tabular}

Table S-3: Raw data of unvegetated core from High Traffic Station (Samouco Salt Marsh) in Summer (September 2011).

\begin{tabular}{|c|c|c|c|c|c|c|c|c|c|c|c|}
\hline & \multirow[b]{2}{*}{$\begin{array}{c}\text { Depth } \\
(\mathrm{cm})\end{array}$} & \multicolumn{4}{|c|}{ sediment } & \multirow{2}{*}{$\begin{array}{c}\text { roots } \\
\begin{array}{c}\mathrm{Pt} \\
\left(\mathrm{ng} \mathrm{g}^{-1}\right)\end{array} \\
\end{array}$} & \multicolumn{5}{|c|}{ interstitial water } \\
\hline & & $\begin{array}{c}\mathrm{Pt} \\
\left(\mathrm{ng} \mathrm{g}^{-1}\right)\end{array}$ & $\begin{array}{c}\mathrm{Al} \\
\left(\mathrm{mg} \mathrm{g}^{-1}\right)\end{array}$ & $\begin{array}{c}\mathrm{Fe} \\
\left(\mathrm{mg} \mathrm{g}^{-1}\right)\end{array}$ & $\begin{array}{c}\mathrm{Mn} \\
\left(\mu \mathrm{g} \mathrm{g}^{-1}\right)\end{array}$ & & $\begin{array}{c}\mathrm{Pt} \\
\left(\mathrm{ng} \mathrm{L}^{-1}\right)\end{array}$ & $\begin{array}{c}\mathrm{Fe} \\
\left(\mathrm{mg} \mathrm{L}^{-1}\right)\end{array}$ & $\begin{array}{c}\mathrm{Mn} \\
\left(\mathrm{mg} \mathrm{L}^{-1}\right) \\
\end{array}$ & $\begin{array}{r}\mathrm{RSS}_{\mathrm{T}} \\
\left(\mu \mathrm{g} \mathrm{L}^{-1}\right)\end{array}$ & salinity \\
\hline HTS overlying & - & - & - & - & - & - & 0.164 & 0.046 & 0.013 & - & 34 \\
\hline HTS 00-02 & 1 & 40.1 & 69.1 & 30.2 & 542 & - & 0.429 & 0.494 & 1.260 & 14400 & 34.5 \\
\hline HST 02-04 & 3 & 2.52 & 78.9 & 31.5 & 518 & - & 0.520 & 4.880 & 1.750 & 3800 & 35 \\
\hline HST 04-06 & 5 & 0.683 & 78.3 & 31.6 & 639 & - & 0.656 & 10.700 & 2.430 & 47.2 & 35 \\
\hline HST 06-08 & 7 & 0.619 & 100 & 41.5 & 613 & - & 0.571 & 1.720 & 2.790 & 43.3 & 36 \\
\hline HST 08-10 & 9 & 0.682 & 115 & 45.7 & 356 & - & 0.592 & 0.254 & 1.380 & 17.2 & 38 \\
\hline HST 10-13 & 11.5 & 0.584 & 110 & 41.9 & 367 & - & 0.589 & 0.423 & 0.790 & 14.4 & 39 \\
\hline HST 13-16 & 14.5 & 0.816 & 113 & 42.0 & 313 & - & 0.484 & 0.039 & 0.497 & 5.35 & 40 \\
\hline HST $16-20$ & 18 & 0.653 & 127 & 45.4 & 347 & - & 0.535 & 0.096 & 0.829 & 5.75 & 40 \\
\hline HST 20-25 & 22.5 & 0.968 & 77.7 & 43.6 & 397 & - & - & - & - & - & - \\
\hline HST $25-30$ & 27.5 & 0.558 & 77.2 & 40.8 & 467 & - & - & - & - & - & - \\
\hline HST 30-35 & 32.5 & 0.605 & 82.3 & 41.2 & 366 & - & - & - & - & - & - \\
\hline HST $35-40$ & 37.5 & 0.516 & 80.7 & 39.4 & 378 & - & - & - & - & - & - \\
\hline HST 40-45 & 42.5 & 0.466 & 80.2 & 40.3 & 278 & - & - & - & - & - & - \\
\hline HST 45-50 & 47.5 & 0.557 & 88.0 & 41.7 & 307 & - & - & - & - & - & - \\
\hline HST 50-55 & 52.5 & 0.572 & 88.5 & 41.1 & 303 & - & - & - & - & - & - \\
\hline HST 55-60 & 57.5 & 0.452 & 81.7 & 38.1 & 261 & - & - & - & - & - & - \\
\hline
\end{tabular}


Table S-4: Raw data of vegetated core (Sarcocornia fruticosa) from High Traffic Station (Samouco Salt Marsh) in Spring (March 2011).

\begin{tabular}{|c|c|c|c|c|c|c|c|c|c|c|c|}
\hline & \multirow[b]{2}{*}{$\begin{array}{c}\text { Depth } \\
(\mathrm{cm})\end{array}$} & \multicolumn{4}{|c|}{ sediment } & \multirow{2}{*}{$\begin{array}{c}\text { roots } \\
\begin{array}{c}\mathrm{Pt} \\
\left(\mathrm{ng} \mathrm{g}^{-1}\right)\end{array}\end{array}$} & \multicolumn{5}{|c|}{ interstitial water } \\
\hline & & $\begin{array}{c}\mathrm{Pt} \\
\left(\mathrm{ng} \mathrm{g}^{-1}\right)\end{array}$ & $\begin{array}{c}\mathrm{Al} \\
\left(\mathrm{mg} \mathrm{g}^{-1}\right)\end{array}$ & $\begin{array}{c}\mathrm{Fe} \\
\left(\mathrm{mg} \mathrm{g}^{-1}\right)\end{array}$ & $\begin{array}{c}\mathrm{Mn} \\
\left(\mu \mathrm{g} \mathrm{g}^{-1}\right)\end{array}$ & & $\begin{array}{c}\mathrm{Pt} \\
\left(\mathrm{ng} \mathrm{L}^{-1}\right)\end{array}$ & $\begin{array}{c}\mathrm{Fe} \\
\left(\mathrm{mg} \mathrm{L}^{-1}\right)\end{array}$ & $\begin{array}{c}\mathrm{Mn} \\
\left(\mathrm{mg} \mathrm{L}^{-1}\right)\end{array}$ & $\begin{array}{c}\mathrm{RSS}_{\mathrm{T}} \\
\left(\mu \mathrm{g} \mathrm{L}^{-1}\right)\end{array}$ & salinity \\
\hline HTS 00-02 & 1 & 0.879 & - & 43.7 & 388 & 0.317 & 0.698 & 1.890 & 1.300 & 81.0 & 17 \\
\hline HST 02-04 & 3 & 1.124 & 69.1 & 35.0 & 329 & 0.210 & 0.471 & 8.540 & 1.590 & 64.0 & 18 \\
\hline HST 04-06 & 5 & 0.543 & 78.9 & 41.2 & 320 & 0.300 & 0.491 & 9.940 & 2.020 & 138 & 18 \\
\hline HST 06-08 & 7 & 0.435 & 78.3 & 38.2 & 319 & 0.287 & 0.522 & 9.040 & 2.400 & 175 & 18 \\
\hline HST 08-10 & 9 & 0.519 & 100 & 39.5 & 317 & 0.374 & 0.540 & 12.10 & 2.610 & 63.0 & 20 \\
\hline HST 10-13 & 11.5 & 0.381 & 115 & 48.0 & 370 & 0.336 & 0.400 & 3.510 & 2.240 & 7.20 & 21 \\
\hline HST 13-16 & 14.5 & 0.405 & 110 & 41.5 & 360 & 0.431 & 0.506 & 4.050 & 2.720 & 6.02 & 23 \\
\hline HST 16-20 & 18 & 0.345 & 113 & 44.3 & 467 & 0.548 & 0.511 & 3.080 & 2.690 & 1.08 & 26 \\
\hline HST 20-25 & 22.5 & 0.443 & 127 & 41.8 & 528 & 0.476 & - & - & - & - & - \\
\hline HST 25-30 & 27.5 & 0.405 & 77.7 & 41.9 & 499 & 0.554 & - & - & - & - & - \\
\hline HST 30-35 & 32.5 & 0.417 & 77.2 & 53.7 & 516 & 0.691 & - & - & - & - & - \\
\hline HST 35-40 & 37.5 & 0.462 & 82.3 & 49.1 & 390 & 0.796 & - & - & - & - & - \\
\hline HST 40-45 & 42.5 & 0.608 & 80.7 & 47.6 & 318 & 0.960 & - & - & - & - & - \\
\hline HST 45-50 & 47.5 & 0.618 & 80.2 & 49.6 & 325 & 0.866 & - & - & - & - & - \\
\hline HST 50-55 & 52.5 & 0.591 & 88.0 & 49.6 & 332 & 0.975 & - & - & - & - & - \\
\hline HST 55-60 & 57.5 & 0.817 & 88.5 & 47.6 & 321 & 0.996 & - & - & - & - & - \\
\hline HST 60-65 & 62.5 & 0.596 & 88.5 & 45.0 & 309 & 1.363 & - & - & - & - & - \\
\hline HST 65-70 & 67.5 & 0.744 & 81.7 & 46.0 & 308 & 1.499 & - & - & - & - & - \\
\hline
\end{tabular}

Table S-5: Raw data of vegetated core (Sarcocornia fruticosa) from High Traffic Station (Samouco Salt Marsh) in Summer (September 2011).

\begin{tabular}{|c|c|c|c|c|c|c|c|c|c|c|c|}
\hline & \multirow[b]{2}{*}{$\begin{array}{c}\text { Depth } \\
(\mathrm{cm})\end{array}$} & \multicolumn{4}{|c|}{ sediment } & \multirow{2}{*}{$\begin{array}{c}\text { roots } \\
\begin{array}{c}\mathrm{Pt} \\
\left(\mathrm{ng} \mathrm{g}^{-1}\right)\end{array}\end{array}$} & \multicolumn{5}{|c|}{ interstitial water } \\
\hline & & $\begin{array}{c}\mathrm{Pt} \\
\left(\mathrm{ng} \mathrm{g}^{-1}\right)\end{array}$ & $\begin{array}{c}\mathrm{Al} \\
\left(\mathrm{mg} \mathrm{g}^{-1}\right)\end{array}$ & $\begin{array}{c}\mathrm{Fe} \\
\left(\mathrm{mg} \mathrm{g}^{-1}\right)\end{array}$ & $\begin{array}{c}\mathrm{Mn} \\
\left(\mu \mathrm{g} \mathrm{g}^{-1}\right)\end{array}$ & & $\begin{array}{c}\mathrm{Pt} \\
\left(\mathrm{ng} \mathrm{L}^{-1}\right)\end{array}$ & $\begin{array}{c}\mathrm{Fe} \\
\left(\mathrm{mg} \mathrm{L}^{-1}\right)\end{array}$ & $\begin{array}{c}\mathrm{Mn} \\
\left(\mathrm{mg} \mathrm{L}^{-1}\right) \\
\end{array}$ & $\begin{array}{r}\mathrm{RSS}_{\mathrm{T}} \\
\left(\mu \mathrm{g} \mathrm{L}^{-1}\right)\end{array}$ & salinity \\
\hline HTS overlying & - & - & - & - & - & - & 0.120 & 0.037 & 0.038 & - & 34 \\
\hline HTS 00-02 & 1 & 5.50 & 80 & 29.3 & 203 & 0.027 & 0.295 & 0.344 & 0.387 & 298 & 35 \\
\hline HST 02-04 & 3 & 0.771 & 106 & 40.6 & 274 & 0.041 & 0.399 & 2.550 & 0.432 & 70.2 & 35 \\
\hline HST 04-06 & 5 & 0.558 & 99.5 & 39.9 & 328 & 0.064 & 0.406 & 36.900 & 1.010 & 182 & 36 \\
\hline HST 06-08 & 7 & 0.527 & 113 & 43.1 & 360 & 0.059 & 0.403 & 77.700 & 1.170 & 90.4 & 37 \\
\hline HST 08-10 & 9 & 0.389 & 120 & 42.7 & 346 & 0.229 & 0.351 & 76.100 & 2.150 & 25.4 & 37 \\
\hline HST 10-13 & 11.5 & 0.368 & 119 & 43.3 & 338 & 0.388 & 0.485 & 31.000 & 2.940 & 30.5 & 39 \\
\hline HST 13-16 & 14.5 & 0.391 & 122 & 43.2 & 401 & 0.362 & 0.423 & 26.900 & 3.540 & 46.9 & 39 \\
\hline HST 16-20 & 18 & 0.484 & 113 & 33.6 & 301 & 0.263 & 1.86 & 16.500 & 2.860 & 13.9 & 40 \\
\hline HST 20-25 & 22.5 & 0.587 & 121 & 37.4 & 320 & - & - & - & - & - & - \\
\hline HST $25-30$ & 27.5 & 0.474 & 139 & 41.8 & 347 & - & - & - & - & - & - \\
\hline HST 30-35 & 32.5 & 0.535 & 124 & 46.1 & 347 & - & - & - & - & - & - \\
\hline HST $35-40$ & 37.5 & 0.809 & 112 & 50.8 & 322 & - & - & - & - & - & - \\
\hline HST 40-45 & 42.5 & 0.614 & 109 & 43.8 & 309 & - & - & - & - & - & - \\
\hline
\end{tabular}


Table S-6: Raw data of vegetated core (Sarcocornia fruticosa) from Low Traffic Station (Rosario Salt Marsh) in Spring (March 2011).

\begin{tabular}{|c|c|c|c|c|c|c|c|c|c|c|c|}
\hline & \multirow[b]{2}{*}{$\begin{array}{c}\text { Depth } \\
(\mathrm{cm})\end{array}$} & \multicolumn{4}{|c|}{ sediment } & \multirow{2}{*}{$\begin{array}{c}\text { roots } \\
\mathrm{Pt} \\
\left(\mathrm{ng} \mathrm{g}^{-1}\right)\end{array}$} & \multicolumn{5}{|c|}{ interstitial water } \\
\hline & & $\begin{array}{c}\mathrm{Pt} \\
\left(\mathrm{ng} \mathrm{g}^{-1}\right)\end{array}$ & $\begin{array}{c}\mathrm{Al} \\
\left(\mathrm{mg} \mathrm{g}^{-1}\right)\end{array}$ & $\begin{array}{c}\mathrm{Fe} \\
\left(\mathrm{mg} \mathrm{g}^{-1}\right)\end{array}$ & $\begin{array}{c}\mathrm{Mn} \\
\left(\mu \mathrm{g} \mathrm{g}^{-1}\right)\end{array}$ & & $\begin{array}{c}\mathrm{Pt} \\
\left(\mathrm{ng} \mathrm{L}^{-1}\right)\end{array}$ & $\begin{array}{c}\mathrm{Fe} \\
\left(\mathrm{mg} \mathrm{L}^{-1}\right)\end{array}$ & $\begin{array}{c}\mathrm{Mn} \\
\left(\mathrm{mg} \mathrm{L}^{-1}\right)\end{array}$ & $\begin{array}{c}\mathrm{RSS}_{\mathrm{T}} \\
\left(\mu \mathrm{g} \mathrm{L}^{-1}\right)\end{array}$ & salinity \\
\hline LTS 00-02 & 1 & 2.75 & 102 & 40.6 & 636 & 0.896 & 0.334 & 0.389 & 6.300 & 26.0 & 25 \\
\hline LST 02-04 & 3 & 1.20 & 111 & 48.5 & 473 & 0.479 & 0.234 & 0.173 & 1.020 & 80.7 & 23 \\
\hline LST 04-06 & 5 & 1.02 & 107 & 46.5 & 322 & 0.336 & 0.156 & 0.125 & 0.812 & 52.1 & 22 \\
\hline LST 06-08 & 7 & 0.906 & 102 & 45.7 & 339 & 0.290 & 0.173 & 0.662 & 1.070 & 53.9 & 22 \\
\hline LST 08-10 & 9 & 0.684 & 107 & 51.4 & 355 & 0.544 & 0.262 & 1.560 & 0.966 & 55.2 & 23 \\
\hline LST 10-13 & 11.5 & 0.588 & 103 & 53.1 & 310 & 0.749 & 0.169 & 3.040 & 1.130 & 65.9 & 24 \\
\hline LST 13-16 & 14.5 & 1.01 & 93.9 & 48.7 & 268 & 1.64 & 2.524 & 6.720 & 1.220 & 12.5 & 27.5 \\
\hline LST 16-20 & 18 & 0.444 & 109 & 42.2 & 247 & 0.180 & 0.143 & 5.030 & 1.200 & 5.59 & 32.5 \\
\hline LST 20-25 & 22.5 & 0.334 & 53.9 & 19.5 & 116 & 0.298 & - & - & - & - & - \\
\hline LST 25-30 & 27.5 & 0.069 & 29.0 & 8.32 & 53.1 & - & - & - & - & - & - \\
\hline LST 30-35 & 32.5 & 0.022 & 26.3 & 6.86 & 49.6 & - & - & - & - & - & - \\
\hline LST $35-40$ & 37.5 & 0.237 & 44.8 & 13.7 & 96.1 & - & - & - & - & - & - \\
\hline LST 40-45 & 42.5 & 0.315 & 54.7 & 16.4 & 111 & - & - & - & - & - & - \\
\hline LST 45-50 & 47.5 & 0.484 & 61.7 & 24.6 & 145 & - & - & - & - & - & - \\
\hline LST 50-55 & 52.5 & 0.369 & 62.0 & 22.8 & 147 & - & - & - & - & - & - \\
\hline LST 55-60 & 57.5 & 0.471 & 63.4 & 20.3 & 151 & - & - & - & - & - & - \\
\hline LST 60-65 & 62.5 & 0.537 & 62.9 & 19.9 & 157 & - & - & - & - & - & - \\
\hline LST $65-70$ & 67.5 & 0.394 & 54.3 & 19.4 & 140 & - & - & - & - & - & - \\
\hline
\end{tabular}


Table S-7: Raw data of vegetated core (Sarcocornia fruticosa) from Low Traffic Station (Rosario Salt Marsh) in Summer (September 2011).

\begin{tabular}{|c|c|c|c|c|c|c|c|c|c|c|c|}
\hline & \multirow[b]{2}{*}{$\begin{array}{c}\text { Depth } \\
(\mathrm{cm})\end{array}$} & \multicolumn{4}{|c|}{ sediment } & \multirow{2}{*}{$\begin{array}{c}\text { roots } \\
\begin{array}{c}\mathrm{Pt} \\
\left(\mathrm{ng} \mathrm{g}^{-1}\right)\end{array}\end{array}$} & \multicolumn{5}{|c|}{ interstitial water } \\
\hline & & $\begin{array}{c}\mathrm{Pt} \\
\left(\mathrm{ng} \mathrm{g}^{-1}\right)\end{array}$ & $\begin{array}{c}\mathrm{Al} \\
\left(\mathrm{mg} \mathrm{g}^{-1}\right)\end{array}$ & $\begin{array}{c}\mathrm{Fe} \\
\left(\mathrm{mg} \mathrm{g}^{-1}\right)\end{array}$ & $\begin{array}{c}\mathrm{Mn} \\
\left(\mu \mathrm{g} \mathrm{g}^{-1}\right)\end{array}$ & & $\begin{array}{c}\mathrm{Pt} \\
\left(\mathrm{ng} \mathrm{L}^{-1}\right)\end{array}$ & $\begin{array}{c}\mathrm{Fe} \\
\left(\mathrm{mg} \mathrm{L}^{-1}\right)\end{array}$ & $\begin{array}{c}\mathrm{Mn} \\
\left(\mathrm{mg} \mathrm{L}^{-1}\right)\end{array}$ & $\begin{array}{c}\mathrm{RSS}_{\mathrm{T}} \\
\left(\mu \mathrm{g} \mathrm{L}^{-1}\right)\end{array}$ & salinity \\
\hline LTS overlying & - & - & - & - & - & - & 0.205 & 0.122 & 0.937 & - & 39 \\
\hline LTS 00-02 & 1 & 1.14 & 108 & 44.3 & 731 & 0.735 & 0.540 & 0.581 & 5.030 & 76.0 & 38 \\
\hline LST 02-04 & 3 & 1.10 & 106 & 46.6 & 346 & 0.528 & 0.383 & 0.222 & 3.120 & 41.6 & 41 \\
\hline LST 04-06 & 5 & 0.981 & 112 & 47.4 & 340 & 0.178 & 0.367 & 0.058 & 3.510 & 16.4 & 45 \\
\hline LST 06-08 & 7 & 0.989 & 106 & 47.3 & 347 & 0.601 & 0.450 & 0.028 & 3.040 & 4.66 & 50 \\
\hline LST 08-10 & 9 & 1.10 & 108 & 48.5 & 307 & 0.810 & 0.420 & 0.015 & 1.960 & 0 & 51 \\
\hline LST 10-13 & 11.5 & 0.614 & 105 & 47.7 & 342 & 1.127 & 0.529 & 0.026 & 1.020 & 0 & 50 \\
\hline LST 13-16 & 14.5 & 0.907 & 107 & 47.8 & 322 & 0.637 & 0.635 & 0.026 & 0.721 & 0 & 48 \\
\hline LST 16-20 & 18 & 0.321 & 105 & 45.0 & 271 & 0.383 & 0.482 & 0.009 & 1.280 & 0 & 47 \\
\hline LST 20-25 & 22.5 & 0.671 & 84.6 & 43.7 & 243 & - & - & - & - & - & - \\
\hline LST 25-30 & 27.5 & 0.112 & 39.7 & 15.8 & 83.4 & - & - & - & - & - & - \\
\hline LST 30-35 & 32.5 & 0.347 & 30.7 & 10.6 & 66.5 & - & - & - & - & - & - \\
\hline LST 35-40 & 37.5 & 0.166 & 44.2 & 18.3 & 108 & - & - & - & - & - & - \\
\hline LST 40-45 & 42.5 & 0.287 & 74.8 & 30.7 & 174 & - & - & - & - & - & - \\
\hline LST $45-50$ & 47.5 & 0.314 & 79.2 & 36.4 & 226 & - & - & - & - & - & - \\
\hline LST 50-55 & 52.5 & 0.296 & 65.5 & 31.0 & 174 & - & - & - & - & - & - \\
\hline LST 55-60 & 57.5 & 0.288 & 68.3 & 30.9 & 193 & - & - & - & - & - & - \\
\hline LST 60-65 & 62.5 & 0.273 & 58.7 & 27.8 & 177 & - & - & - & - & - & - \\
\hline
\end{tabular}

Table S-8: Bibliographic Pt concentrations in different sediments: contaminated and background values (Cobelo-García et al., 2013; Fritsche and Meisel, 2004; Peucker-Ehrenbrink and Jahn, 2001; Prego et al., 2011; Rauch et al., 2004a, 2004b; Schäfer and Puchelt, 1998; Sutherland et al., 2007; Tuit et al., 2000; Whiteley and Murray, 2005).

\begin{tabular}{llcc}
\hline Sediments from & Authors & \multicolumn{2}{c}{ Pt $\left(\mathrm{ng} \mathrm{g}^{-1}\right)$} \\
\cline { 2 - 3 } Loess & & contam. & backgr. \\
Peat bog & Peucker and Jahn 2001 & - & 0.51 \\
Harbour & Rauch et al., 2004b & $2.7-290$ & - \\
Urban lake & Tuit et.al., 2000 & $1.8-36$ & $0.2-0.8$ \\
Urban watersheds & Rauch et al., 2004a & $11-30$ & $1.0-1.7$ \\
Urban Infiltration & Sutherland et al., 2007 & $57-70$ & - \\
Road side & Whiteley-Murray, 2005 & $9-100$ & 0.99 \\
Road dust & Fritsche-Meisel, 2004 & $9.1-130$ & $0.16-0.28$ \\
Road side soil & Schäfer-Puchelt, 1998 & $12-1100$ & - \\
Estuarine & Schäfer-Puchelt, 1998 & $20-200$ & $0.40-3.0$ \\
Pristine lagoon & Cobelo-García et al., 2013 & $1-2.1$ & $0.3-0.6$ \\
Salt marsh & Prego et al., 2011 & - & $0.15-0.38$ \\
\hline
\end{tabular}


Table S-9: Values of trace elements concentration in pore water from previous studies in Low Traffic Station for unvegetated (Caetano et al., 1997) and vegetated sediments under Sarcocornia fruticosa (Santos-Echeandía et al., 2010) and typical oceanic waters values (Bruland and Lohan, 2006; Colodner, 1991).

\begin{tabular}{cccc}
\hline element & $\begin{array}{c}\text { interstitial water } \\
\text { unvegetated }\left(\mathrm{ng} \mathrm{L}^{-1}\right)\end{array}$ & $\begin{array}{c}\text { interstitial water } \\
\text { vegetated }\left(\mathrm{ng} \mathrm{L}^{-1}\right)\end{array}$ & $\begin{array}{c}\text { oceanic water } \\
\left(\mathrm{ng} \mathrm{L}^{-1}\right)\end{array}$ \\
\hline $\mathrm{Fe}$ & $140000-330000$ & $9500-3600000$ & $1.1-120$ \\
& & $9000-6700000^{*}$ & $3.3-290$ \\
$\mathrm{Mn}$ & $560000-13000000$ & $320000-770000$ & \\
& & $720000-6300000^{*}$ & $3.3-620$ \\
$\mathrm{Zn}$ & - & $78000-920000$ & $34-300$ \\
$\mathrm{Cu}$ & - & $1700-11000$ & $1.0-33$ \\
$\mathrm{~Pb}$ & - & $6000-56000$ & $0.11-120$ \\
$\mathrm{Cd}$ & - & $30-6500$ & $0.02-0.08$ \\
$\mathrm{Pt}$ & $0.26-0.66^{*}$ & $0.14-2.5^{*}$ & \\
\hline
\end{tabular}

*data from this study

Table S-10: Values of several elements in the belowground and aboveground tissues of Sarcocornia fruticosa from bibliography (Caçador et al., 2009; Caetano et al., 2008) and this study. Values from (Caetano et al., 2008) are averaged between the highest and the lowest concentrations given in this manuscript.

\begin{tabular}{lccccc}
\hline & Belowground tissues & & \multicolumn{3}{c}{ Aboveground tissues } \\
\cline { 2 - 5 } \cline { 5 - 6 } element & Roots $\left(\mu \mathrm{g} \mathrm{g}^{-1}\right)$ & & Stems $\left(\mu \mathrm{g} \mathrm{g}^{-1}\right)$ & Leaves $\left(\mu \mathrm{g} \mathrm{g}^{-1}\right)$ & Average $\left(\mu \mathrm{g} \mathrm{g}^{-1}\right)$ \\
\hline $\mathrm{Fe}$ & 3800000 & - & - & 9000 \\
$\mathrm{Mn}$ & 110 & - & - & 27 \\
$\mathrm{Zn}$ & 5600 & - & - & 45 \\
& $990 \pm 560$ & $28 \pm 22$ & $24 \pm 18$ & $26 \pm 19$ \\
$\mathrm{Cr}$ & 21 & - & - & 1.1 \\
$\mathrm{Ni}$ & 28 & - & - & 0.53 \\
$\mathrm{Cu}$ & 250 & - & - & 3.1 \\
& $290 \pm 50$ & $6.5 \pm 2.2$ & $5.9 \pm 1.9$ & $6.2 \pm 2.0$ \\
$\mathrm{As}$ & 650 & - & - & 0.79 \\
$\mathrm{Cd}$ & 23 & - & - & 0.021 \\
& $7.0 \pm 2.8$ & & $0.31 \pm 0.13$ & $0.21 \pm 0.14$ & $0.26 \pm 0.14$ \\
$\mathrm{Co}$ & $16 \pm 3$ & $8.3 \pm 3.2$ & $6.6 \pm 2.7$ & $7.4 \pm 2.9$ \\
$\mathrm{Pt}$ & $0.9 \pm 0.6^{*}(1)$ & & $0.029 \pm 0.039^{*}$ & $0.043 \pm 0.061^{*}$ & $0.036 \pm 0.048^{*}$ \\
& $(n=43)$ & & $(n=4)$ & $(n=4)$ & $(n=8)$ \\
\hline
\end{tabular}

* data in $\mathrm{ng} \mathrm{g}^{-1} ;{ }^{(1)}$ average concentration without considering adsorption data: $0.6 \pm 0.4(\mathrm{n}=33)$ 